\title{
NOTES ON MALESIAN FABACEAE (LEGUMINOSAE-PAPILIONOIDEAE) 11. The genus Derris
}

\author{
FRITS ADEMA \\ Nationaal Herbarium Nederland, Leiden Universiteit branch, \\ P.O. Box 9514, 2300 RA Leiden, The Netherlands
}

\begin{abstract}
SUMMARY
Derris Lour. is revised for the Flora Malesiana region. In the introduction comments are given on some characters and the seedlings of $D$. trifoliata Lour. are described. The introduction is followed by a section 'Notes on species' in which the varieties of D. elegans Graham ex Benth. are described, including a new one from Celebes (var. celebica Adema) and a new one from Malaysia, Java, Borneo, the Philippines and the Moluccas (var. korthalsiana (Blume ex Miq.) Adema). Several other species are discussed at some length. A key to the species of Derris in Malesia is presented. The paper concludes with notes on aberrant specimens and excluded species.
\end{abstract}

Key words: Derris, Malesia, new varieties, seedlings.

\section{INTRODUCTION}

Derris Lour. is a mostly SE Asian genus of c. 50 species of Millettioid Papilionoideae. One coastal species, D. trifoliata Lour., is widespread and also found in Africa, India, Sri Lanka, Australia and the Pacific; one species is endemic to N Australia (D. involuta (Sprague) Sprague). In the Flora Malesiana region 17 species are found.

In a recent paper (Adema, 2001) the relationship of Derris-like genera was discussed. There I concluded that Brachypterum (Wight \& Arn.) Benth. (see Geesink, 1984) had to be reunited with Derris s.s. In the present paper I will discuss some characters and several species and their varieties. In D. elegans Graham ex Benth. two new varieties are distinguished. Derris ferruginoides, D. micans, D. mindorensis and D. pubipetala are united in one species; also united are D. cebuensis and D. spanogheana.

A key to Malesian species is offered. Notes on several aberrant specimens, and on dubious and excluded species are included.

\section{Inflorescences}

I have revised various genera of Leguminosae and in most cases the scheme for the inflorescences described by Geesink (1984) performs quite well. However, I have found an increasing number of occasions where it is very difficult to decide whether a certain inflorescence is a panicle with rather short lateral branches or a pseudoraceme with (at the base) very long brachyblasts. An example of this is D. koolgibberah where both panicles and pseudoracemes occur. Individual specimens may show this in a single inflorescence: at base clearly a panicle with rather short lateral branches, upwards 


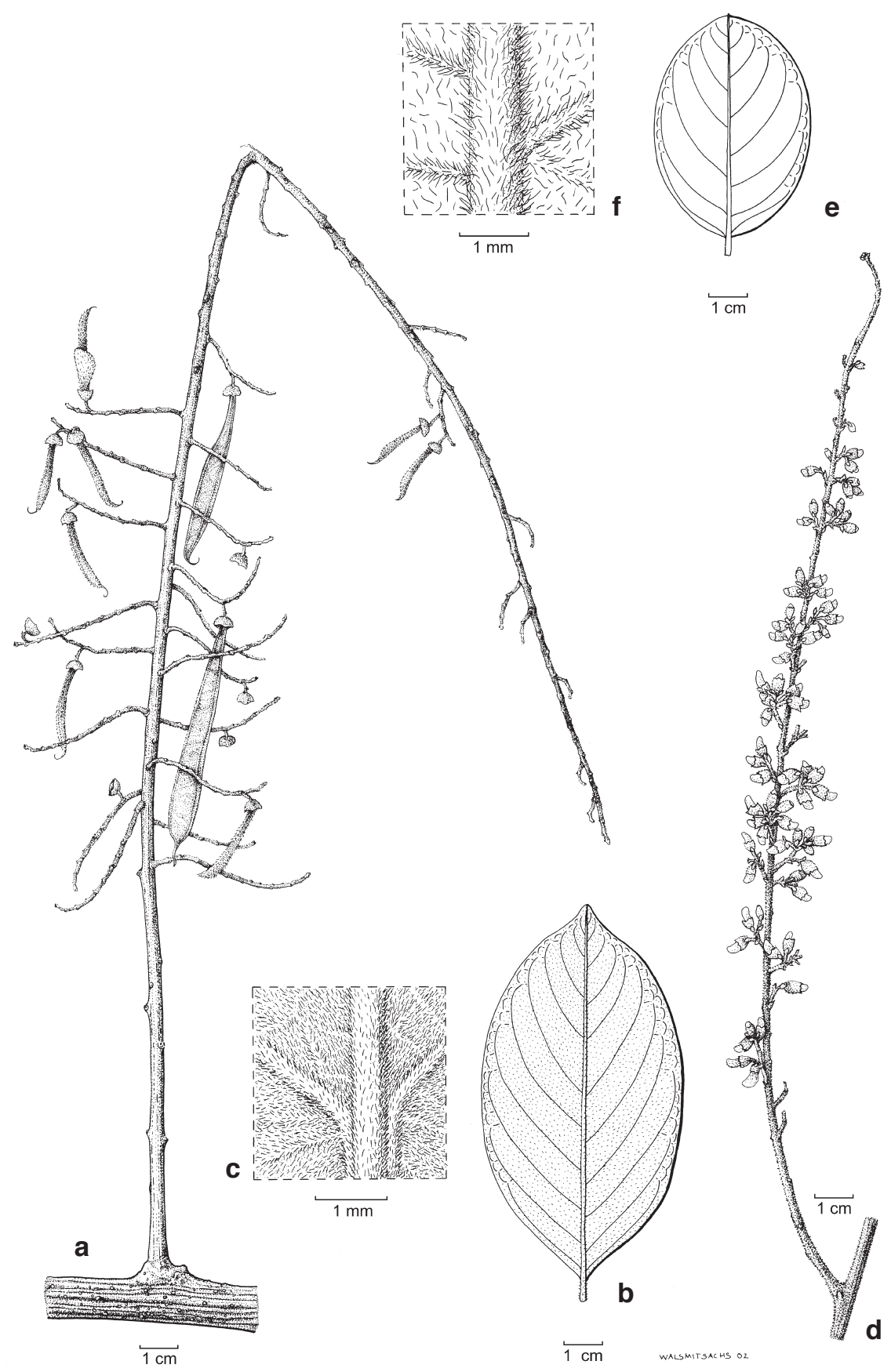

Fig. 1.Leaflets and inflorescences. a-c: Derris koolgibberah F.M. Bailey. a. Inflorescence with young fruits; b. leaflet from below; c. leaflet from below, detail. d-f: D. pseudoinvoluta (Verdc.) Adema. d. inflorescence; e. leaflet from below; f. leaflet from below, detail (a: NGF 22652; b, c: Brass 8205; d-f: NGF 15395). 
these branches become shorter and shorter, finally ending in brachyblasts and the top of the inflorescence could be called a pseudoraceme (Fig. 1a). Similar cases have been described by Buijsen (1988: 240, 249 (lead 7, 9), 250, 251), Dasuki \& Schot (1991: 191, 193 (lead11)) and Schot (1991: 206) for Fordia.

In cases like those described above there is a continuous transition from panicles to pseudoracemes.

\section{Stamens}

In most genera of Leguminosae I have revised so far the filaments and anthers are usually glabrous. Hairy filaments and/or anthers are found in Aganope, Austrosteenisia, Clitoria, Derris, Indigofera, Millettia, Paraderris and Teramnus (Table 1). In Millettia all species with at least some hairs on the anthers belong to sect. Fragiliflorae (Adema, 2000). In Derris it may be a useful character to distinguish D. koolgibberah and $D$. rubrocalyx, which usually have hairy anthers, from $D$. trifoliata, which has glabrous anthers.

\section{Seedlings}

Seedlings are not very often collected. In all Derris material I have studied only one collection of seedlings was found. This collection belongs to D. trifoliata.

Table 1. Hairiness of stamens.

\begin{tabular}{|c|c|c|}
\hline Species & Filaments & Anthers \\
\hline Aganope heptaphylla & glabrous or with scattered hairs & $\begin{array}{l}\text { glabrous or with some hairs at the } \\
\text { connective }\end{array}$ \\
\hline Aganope thyrsiflora & glabrous or with scattered hairs & $\begin{array}{l}\text { glabrous or with some hairs at the } \\
\text { connective }\end{array}$ \\
\hline Austrosteenisia blackii & with some hairs & glabrous \\
\hline Clitoria laurifolia & with few short glandular hairs & glabrous \\
\hline Derris koolgibberah & glabrous or with some hairs & glabrous or with some hairs \\
\hline Derris rubrocalyx & glabrous or with some hairs & often with some (at least one!) hairs \\
\hline Derris 'spec. B' & glabrous or with some hairs & hairy \\
\hline Indigofera decora & glabrous & tuft of hairs at apex and base \\
\hline Indigofera zollingeriana & glabrous & hairy at apex \\
\hline Millettia ahernii & glabrous & hairy at least at the base \\
\hline Millettia borneensis & glabrous & some hairs at the base \\
\hline Millettia brachycarpa & glabrous & some hairs at the base \\
\hline Millettia glabra & glabrous & some hairs at the base \\
\hline Millettia merrillii & glabrous & some hairs at the base \\
\hline Millettia pinnata & glabrous & some hairs at the base \\
\hline Millettia platyphylla & glabrous & hairy at base and apex \\
\hline Millettia tenuipes & glabrous & hairy at the base \\
\hline Millettia velvetina & glabrous & some hairs at the base \\
\hline Millettia xylocarpa & glabrous & glabrous or some hairs at the base \\
\hline Paraderris elliptica & rarely some hairs at free parts & glabrous or with some hairs \\
\hline Paraderris lianoides & glabrous & glabrous or with some hairs \\
\hline Paraderris montana & glabrous & glabrous or rarely with some hairs \\
\hline Paraderris oblongifolia & glabrous & glabrous to slightly hairy \\
\hline Paraderris piscatoria & glabrous & with some hairs \\
\hline Teramnus flexilis & glabrous or with some hairs & with some hairs at the base \\
\hline
\end{tabular}


Derris trifoliata Lour.

Seedlings: Heliciopsis type, Heliciopsis subtype (De Vogel, 1979): Seed coat and fruit wall still present around cotyledons in seedlings.

First leaves (up to at least 10) unifoliolate, usually alternate (very first leaves not seen), ovate to ovate-cordate, coriaceous, $15-52$ by $6-25 \mathrm{~mm}$, base rounded to subpeltate, apex acuminate, glabrous above and below, midrib and nerves raised above; petiole with few hairs along the margin of the groove; stipules triangular, 1 by $1 \mathrm{~mm}$, ciliate. Root nodules present.

Specimen seen: Monod de Froideville 850, Peninsular Malaysia, Port Dickson, 22.02.1946.

Note: Six specimens are mounted on the same sheet. Five belong to D. trifoliata; the sixth differs in several characters.

Up to now I have only seen seedlings of Aganope thyrsiflora (Benth.) Polhill (Maxwell 78-389, 81-23). They have the same germination type as D. trifoliata. De Vogel (1979) also cites this type (Heliciopsis type, Heliciopsis subtype) for Spatholobus.

\section{NOTES ON SPECIES}

\section{A. Derris elegans}

Derris elegans Graham ex Benth. is a very variable widespread species. The extremes look so different that they have been described several times as separate species (Bentham, 1852; Miquel, 1855; Baker, 1879; Hemsley, 1895; Schumann \& Lauterbach, 1901, Pulle 1910; Kanehira \& Hatusima, 1942; Thothathri, 1970). However, several attempts have been made to unite the diverse elements into one species and to accommodate the differences by describing several varieties (Prain, 1897; Verdcourt, 1978, 1979). During a training course in systematics, students at the Nationaal Herbarium Nederland at Leiden concluded that the overlap in certain characters is so large that

Table 2. Differences between the varieties of Derris elegans Graham ex Benth.

\begin{tabular}{llllc}
\hline & var. elegans & var. korthalsiana & var. celebica & var. gracillima \\
\hline $\begin{array}{l}\text { indumentum lower } \\
\text { surface leaflets }\end{array}$ & $\begin{array}{c}\text { densely hirsute } \\
\text { to velvety }\end{array}$ & $\begin{array}{c}\text { scattered appressed } \\
\text { hairs }\end{array}$ & $\begin{array}{c}\text { scattered appressed } \\
\text { hairs }\end{array}$ & $\begin{array}{c}\text { scattered appressed } \\
\text { hairs }\end{array}$ \\
ultrajugal part (mm) & $0-24$ & $0-29$ & $0-7$ & $9-50$ \\
mean & 7.4 & 12.5 & 2.1 & 25 \\
shape leaflets & elliptic to obovate & elliptic to obovate, & obovate & elliptic to obovate, \\
& & rarely ovate & rarely ovate \\
apex of leaflets & obtuse to rounded, & shortly, broadly & obtuse to rounded & long, slender \\
& emarginate or & acuminate, rarely & & acuminate \\
& shortly, broadly & rounded & & \\
acuminate & & 3-13 & 5-25 \\
length acumen (mm) & $0,2-3$ & Peninsular Malaysia, Celebes & New Guinea, \\
distribution & Indochina, Thai- & Solomon Islands, \\
& land, Peninsular & Sumatra, Java, & New Hebrides \\
& Malaysia, & Borneo, Philippines, & \\
& Sumatra, Borneo & Moluccas & & \\
\hline
\end{tabular}


even discriminating varieties is impossible. Indeed, specimens belonging to this species have a lot in common: stipellae always present; leaves with 3 or 5 leaflets; short 2- or 3-flowered brachyblasts; small, rather hairy calyces; standard usually quite hairy; pods with a narrow wing along the upper suture and thinly hirsute valves. However, there are several constant differences in some characters in plants from Continental Asia, Celebes, New Guinea, the Solomon Islands and the New Hebrides (Table 2, Fig. 2). From Table 1 it is obvious that there are overlaps even in those characters. Comparing the characters in which the groups in D. elegans differ, with characters used for species delimitation in Derris, and keeping in mind the large overlaps in other characters, I have decided that it is better to keep all elements together in one species and deal with the differences at the varietal level.

\section{KEY TO THE VARIETIES OF DERRIS ELEGANS}

1a. Lower surface of leaflets with few widely scattered appressed hairs, seemingly

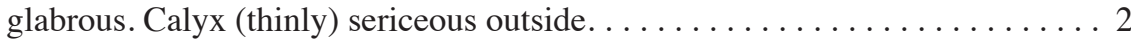

b. Lower surface of leaflets densely hirsute to \pm velvety. Calyx hirsute outside. . . . .

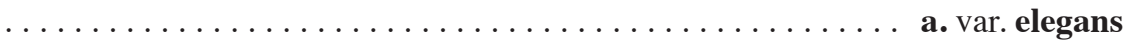

2a. Topmost part of leaf rachis $0-50 \mathrm{~mm}$ long, usually longer than $9 \mathrm{~mm}$. Apex of leaflets short and broad to rather long and slender acuminate, rarely rounded, acu-

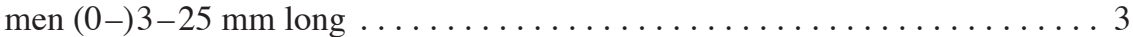

b. Topmost part of leaf rachis $0-7 \mathrm{~mm}$ long. Apex of leaflets obtuse to rounded, emar-

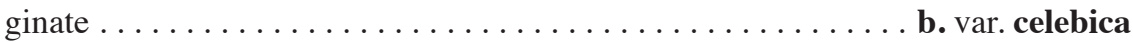

3a. Topmost part of leaf rachis $9-50 \mathrm{~mm}$ long, mean c. $24 \mathrm{~mm}$. Apex of leaflets long and slender acuminate, acumen 5-25 mm long. - New Guinea, Solomon Islands, New Hebrides . . . . . . . . . . . . . . . . c. var. gracillima

b. Topmost part of leaf rachis 0-29 mm long, mean c. $13 \mathrm{~mm}$. Apex of leaflets shortly and broadly acuminate, rarely rounded, acumen (0-)3-13 mm long. - Sumatra, Peninsular Malaysia, Java, Borneo, Philippines . . . . . . . d. var. korthalsiana

a. var. elegans - Fig. $2 c, d$

Derris vestita Baker (1879) 242. - Derris elegans Graham ex Benth. var. vestita (Baker) Prain (1897)103; Ridl. (1922) 597; Craib (1928) 488; Verdc. (1978) 468; (1979) 320. - Type: Maingay 608 (1633) (holo K; iso L), Malacca.

Derris rufula K. Schum. \& Lauterb. (1901) 361. - Lectotype (here designated): Lauterbach 2821 ('821') (holo K), New Guinea.

Stems and twigs usually hirsute, glabrescent. Topmost part (ultrajugal part) of leaf rachis 0-24 mm long, mean $7.4 \mathrm{~mm}$. Leaflets: terminal elliptic to obovate, $6.5-20$ by $2.5-9$ $\mathrm{cm}$, index 1.6-2.8, base rounded or subpeltate, rarely cuneate, apex obtuse to rounded or shortly, broadly acuminate, acumen 2-3 mm long, rounded, above glabrous or \pm hirsute on midrib and nerves in lower part, below hirsute to velvety, often much less hairy in older leaflets, then mostly along midrib (and nerves), midrib and nerves raised above, nerves 6-10 per side, 6-29 mm apart; lateral leaflets mostly as the terminal, (broadly) ovate to elliptic, $4.5-16.5$ by $3-7.5 \mathrm{~cm}$, index $1.5-2.9$; pulvinus $2-9 \mathrm{~mm}$ long, hirsute. Calyx brown purple, outside hirsute. 


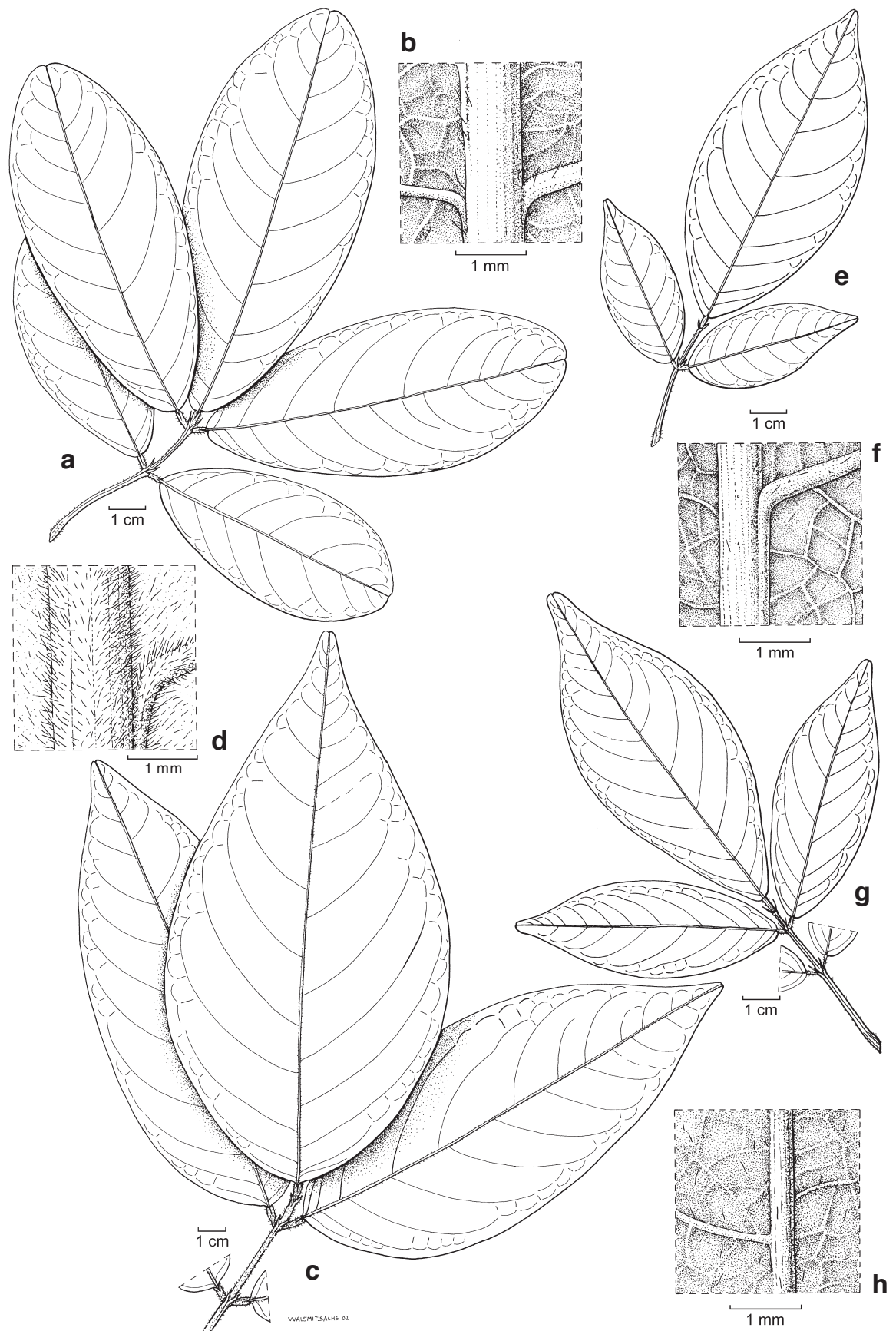

Fig. 2. Derris elegans Graham ex Benth. Details of leaves and lower surface of leaflets. - a, b. var. celebica Adema; c, d. var. elegans; e, f. var. gracillima (Hemsl.) Verdc.; g, h. var. korthalsiana (Blume ex Miq.) Adema (a, b: Prawiroatmodjo \& Soewoko 1851; c, d: Chin \& Mustafa 3305; e, f: BW 15292 (W. \& M. Vink); g, h: SAN 17291 (D.T. Nicholson)). 
Distribution - Burma, Andaman Islands, Indochina, Thailand; Malesia: Sumatra, Peninsular Malaysia, Borneo (Sabah), Papua New Guinea (W Sepik Province).

Habitat \& Ecology - Primary forests along rivers. Soil: sandstone. Altitude up to 300 m. Flowering: January to March, July to September; fruiting: March, April, July, August.

b. var. celebica Adema, var. nov. - Fig. 2a, b

Partes axiales plerumque parce hirsutae ad glabrae, folii rachidis ultrajugo parte $0-7 \mathrm{~mm}$ longa (medium $2.1 \mathrm{~mm}$ ). Foliola: terminalia (anguste) obovata raro elliptica 6-19 cm longa $3-7.5 \mathrm{~cm}$ lata (indice $2-3.5$ ), basi rotundata ad cuneata, apice obtuso ad rotundato emarginato, supra glabra, infra pilis paucis sparsis appressa ad fere glabra, costa nervique supra prominentibus, nervis $6-11$ in quoque latere $5-19 \mathrm{~mm}$ distantibus; lateralibus terminalibus plerumque similibus ellipticis ad anguste obovatis $4.5-13.5 \mathrm{~cm}$ longis $2-5.5$ $\mathrm{cm}$ latis (indice 1.9-3.6), pulvino $2-6 \mathrm{~mm}$ longo glabro ad pilis paucis, calyx viridis vel triste rubra extus sericea. - Typus: Forsten s.n. (holo L), Celebes, Gorontalo.

Stems and twigs usually thinly hirsute to glabrous. Topmost part (ultrajugal part) of leaf rachis 0-7 mm long, mean $2.1 \mathrm{~mm}$. Leaflets: terminal (narrowly) obovate, rarely elliptic, $6-19$ by $3-7.5 \mathrm{~cm}$, index $2-3.5$, base rounded to cuneate, apex obtuse to rounded, emarginate, above glabrous, below with few widely scattered appressed hairs to almost glabrous, midrib and nerves raised above, nerves 6-11 per side, 5-19 mm apart; lateral leaflets mostly as the terminal, elliptic to narrowly obovate, $4.5-13.5$ by $2-5.5 \mathrm{~cm}$, index 1.9-3.6; pulvinus 2-6 mm long, glabrous or with few hairs. Calyx green or dull red, outside sericeous.

Distribution - Malesia: Celebes.

Habitat \& Ecology - Primary or savannah forest. Soil: limestone, shale. Altitude up to 200 m. Flowering: August, October; fruiting: September to November.

Note - According to the label Eyma 4094 is a shrub; Eyma 4128 is a small tree. The latter specimen has shorter inflorescences and a second auricle (lower) at the wing petals.

c. var. gracillima (Hemsl.) Verdc. - Fig. 2e, f

Derris elegans Graham ex Benth. var. gracillima (Hemsl.) Verdc. (1978) 468; (1979) 320. - Millettia gracillima Hemsl. (1895) 34. - Type: Comins 300 (holo K), Solomon Islands, San Cristobal.

Derris cauliflora Pulle (1910) 379. - Type: Versteeg 1714 (holo L), Papua.

Derris papuana Pulle (1910) 380. - Type: Versteeg 1754 (holo L), Papua.

Derris moniensis Kaneh. \& Hatus. (1942) 364, f. 5. - Type: Kanehira \& Hatusima 13255 (photo seen), Papua.

Derris salomoniensis Thoth. (1970) 251. - Type: Kajewski 2290 (holo A; iso E, L), Solomon Islands, Bougainville Island.

Stems and twigs thinly strigose to glabrous. Topmost part (ultrajugal part) of leaf rachis $9-50 \mathrm{~mm}$ long, mean $25 \mathrm{~mm}$. Leaflets: terminal elliptic, rarely obovate, 11-25 by $4.5-12 \mathrm{~cm}$, index $1.5-2.8$, base rounded, apex long and slender acuminate, acumen 5-25 mm long, above glabrous, below with few widely scattered appressed hairs, midrib and nerves raised above, nerves 9-11 per side, 10-24 mm apart; lateral leaflets mostly as the terminal, narrowly ovate to elliptic, $7.5-20$ by $2.5-10.5 \mathrm{~cm}$, index $1.1-3$; pulvinus 4-8 mm long, almost glabrous. Calyx brown to reddish, outside thinly sericeous. 
Distribution - Malesia: New Guinea; Solomon Islands; New Hebrides.

Habitat \& Ecology - Primary or secondary forests along rivers. Soil: sand, clay or limestone silt. Altitude up to $600 \mathrm{~m}$. Flowering: June to October; fruiting: January, March, October to December.

Uses - In Bougainville used for binding in native house construction.

Note $-B W 15292$ (W. \& M. Vink) probably belongs here. According to the label this specimen is a shrub with orange brown ripe fruits.

d. var. korthalsiana (Blume ex Miq.) Adema, comb. \& stat. nov. - Fig. 2g, h

Derris korthalsiana Blume ex Miq. (1855) 143. - Type: Korthals s.n. (holo L), Borneo.

Stems and twigs thinly strigose or hirsute. Topmost part (ultrajugal part) of leaf rachis 0-29 mm long, mean $12.5 \mathrm{~mm}$. Leaflets: terminal elliptic to obovate, rarely ovate, $4-35$ by $3-11 \mathrm{~cm}$, index $1.8-2.8$, base rounded, apex shortly and broadly acuminate, acumen 3-13 mm long, rounded, above glabrous, below with few widely scattered appressed hairs, midrib and nerves raised above, nerves 7-11 per side, 5-20 mm apart; lateral mostly as the terminal, elliptic to ovate, rarely narrowly obovate, 4-21.5 by 2-10.5 cm, index 1.9-2.7; pulvinus 3-8 mm, long, with few hairs. Calyx brownish to red, outside (thinly) sericeous.

Distribution - Malesia: Sumatra, Peninsular Malaysia (Kelantan, Perak), Java, Borneo, Philippines, Moluccas (Ambon, Ceram).

Habitat \& Ecology - Primary or secondary forests along rivers. Soil: sand, clay, loam, limestone. Altitude up to $500 \mathrm{~m}$. Flowering: January to April, August to November; fruiting: February to October.

Notes - 1. Flower colour once given as 'magenta red'.

2. SAN 34191 (J. Ampura) probably belongs here. The pods of this specimen are 2-winged: upper wing 2.5-3 mm, lower wing $1 \mathrm{~mm}$ wide. Ramlanto 383 is included here. This specimen also has 2-winged pods (upper wing $2-4 \mathrm{~mm}$, lower wing $1 \mathrm{~mm}$ wide). In all other aspects these specimens are similar to D. elegans.

\section{B. Derris ferruginoides, D. micans, D. mindorensis and D. pubipetala}

These four species are closely related and quite similar in most characters. Perkins (1904) described $D$. micans based on fruiting material and $D$. mindorensis on flowering specimens. The two species are very similar in vegetative characters. Derris pubipetala was described by Miquel (1855) from Java. The differences between D. micans/mindorensis and D. pubipetala are very small. Derris ferruginoides was described by Quisumbing (1930) for densely hairy specimens that did not fit in the description of D. mindorensis in having 2 or 3 instead of $3-5$ ovules.

In constructing the key for the species of Derris these taxa were problematic, as they do not obviously differ in their characters. Also the geographical distributions of D. pubipetala and D. mindorensis overlapped considerably. Considering all characters and comparing this group of species with other Derris species led me to conclude that only one species is involved. The oldest name available for this taxon is: D. pubipetala Miq. 


\section{Derris pubipetala Miq.}

Derris pubipetala Miq. (1855) 115. - Type: Blume s.n. (holo U?; iso A, K, U), Java.

Derris acuminata Miq. (1855) 115, nom. illeg. non Benth. (1852); Backer \& Bakh.f. (1964) 619. - Type: Blume s.n. (holo U), Java.

Derris mindorensis Perkins (1904) 82; Merr. (1923) 300. - Type: Merrill 953 (holo ?; iso K), Philippines, Mindoro, Palauan.

Derris micans Perkins (1904) 82; Merr. (1923) 300. - Type: Merrill 2284 (holo ?; iso K), Philippines, Luzon, Tanay.

Derris ferruginoides Quisumb. (1930) 324. - Type: Clemens 7406 (holo UC?), Philippines, Luzon.

In this new circumscription the species is quite variable in its indumentum. It is also more widespread occurring in: Sumatra, Peninsular Malaysia (Perak), Borneo, Philippines (Luzon, Mindoro, Mindanao, Palawan), Celebes.

Derris pubipetala is in many characters very similar to the northern species D. ferruginea (Roxb.) Benth. The two species differ mainly in the shape of the apex of the leaflets: which is rounded or cuspidate to shortly acuminate in D.ferruginea and acuminate (acumen 2-10 mm long) in D.pubipetala; the flower colour which is white or greenish in D. pubipetala and purple in D.ferruginea (Thothathri, 1982; however, Maxwell 89-64 from Thailand has white flowers); and in the wings of the fruits which are very unequal with the lower one almost absent to c. $1 \mathrm{~mm}$ wide in $D$. ferruginea and less unequal with the lower one $2-4 \mathrm{~mm}$ wide in D.pubipetala.

\section{Derris koolgibberah and its subspecies}

1. Derris koolgibberah F.M. Bailey (Fig. 1a-c) is a species that occurs in Australia and Papua New Guinea. Verdcourt $(1978,1979)$ described two subspecies: subsp. koolgibberah and subsp. pseudoinvoluta Verdc. Of the latter subspecies he suggested that a closer study might reveal it to be a valid species. In the course of my revision of Derris for Flora Malesiana I found that he was right and have subsequently raised that subspecies to the species level (Adema, 2001, see also below).

The Papua New Guinean material that remains in D. koolgibberah, is quite variable. Although represented by only eleven specimens, there are at least five 'entities' recognisable. These entities differ in indumentum, thickness of leaflets, and in the size of the flower parts:

a) Carr 16056, NGF 4196, 22652 from Madang and Central Provinces: Indumentum \pm strigose; leaflets rather thin; inflorescence a panicle; flowers c. $12 \mathrm{~mm}$ long, longer than those of ' $\mathrm{B}$ ' or ' $\mathrm{D}$ '.

b) Darbyshire 1121, LAE 73396 from Western Highlands and Northern Provinces: Indumentum \pm hirsute; leaflets rather thick; inflorescence a panicle; flowers c. 8 mm long; staminal tube and anthers with some hairs.

c) Brass 8205 from Western Province: Indumentum \pm hirsute; leaflets rather thin, inflorescence a panicle. Known only in fruit.

d) Brass 29202, Hartley 10158, NGF 9961, 9978 from Morobe Province: Indumentum \pm strigose; leaflets rather thin; inflorescence a pseudoraceme; flowers up to $8 \mathrm{~mm}$ long. 
e) Brass 29494 from Milne Bay Province: Indumentum \pm hirsute; leaflets rather thin; base of leaflets cordate; flowers c. $8 \mathrm{~mm}$ long; corolla lavender; staminal tube and anthers with some hairs.

Most differences are rather small and overlaps in measurements occur. There is much more material needed to solve this problem. For the moment the species is accepted as a complex species.

2. Derris pseudoinvoluta (Verdc.) Adema - Fig. 1d-f

Derris pseudoinvoluta (Verdc.) Adema (2001) 11. - Derris koolgibberah F.M. Bailey subsp. pseudoinvoluta Verdc. (1978) 469; (1979) 321. - Type: NGF 15395 (Womersley) (K, L, LAE), Papua New Guinea, Lae.

Derris pseudoinvoluta: Leaflets woolly below. Stipellae present, caducous. Ovules 7-10.

Derris koolgibberah: Leaflets thinly strigose or thinly hirsute below. Stipellae absent. Ovules 10.

\section{Derris polyantha}

Derris polyantha Perkins was described by Perkins (1904) from Luzon. Up to now it was known only from that island and only from flowering material. Recently several collections have emerged from Cebu: Bicknell 677, 1190, 1190b, PNH 92130. These plants are vegetatively rather similar to $D$. polyantha, and indeed invariably key out to that species. These Cebu specimens are mostly in fruit. The only flowering specimen (Bicknell 1190) does not vary much from the Luzon specimens. I have therefore included all these specimens in the description of $D$. polyantha. The fruits of this species can be described as follows: Pods \pm strap-shaped, $5-7.5$ by $1-2 \mathrm{~cm}$, valves thinly sericeous, upper wing 2-3 $\mathrm{mm}$, lower wing up to $0.5 \mathrm{~mm}$ wide.

\section{E. Derris cebuensis, D. rubrocalyx, D. spanogheana and D. trifoliata}

These species are closely related and differ only slightly in some characters. All are mostly glabrous with hairs only present in young stages and in some parts of the in-

Table 3. Differences between Derris cebuensis Merr., D. rubrocalyx Verdc., D. spanogheana Blume ex Miq. and D. trifoliata Lour.

\begin{tabular}{|c|c|c|c|c|}
\hline & D. cebuensis & D. rubrocalyx & D. spanogheana & D. trifoliata \\
\hline number of leaflets & $3-7$ & ( 3 or) 5 & 7 & $3-7$ \\
\hline base of leaflets & cuneate to rounded & cuneate to rounded & rounded & $\begin{array}{l}\text { rounded or } \pm \text { cor- } \\
\text { date to subpeltate }\end{array}$ \\
\hline length of brachyblasts & up to $30 \mathrm{~mm}$ & up to $30 \mathrm{~mm}$ & 9-18 mm & up to $5 \mathrm{~mm}$ \\
\hline $\begin{array}{l}\text { number of flowers } \\
\text { per brachyblast }\end{array}$ & $6-8$ & up to 15 & $7-12$ & 2 or 3 (or 5$)$ \\
\hline width upper wing & $5-10 \mathrm{~mm}$ & $2-6 \mathrm{~mm}$ & - & $1-5 \mathrm{~mm}$ \\
\hline width lower wing & $4-7 \mathrm{~mm}$ & $2-4 \mathrm{~mm}$ & - & - \\
\hline
\end{tabular}


florescences. Differences are found in the number of leaflets, the shape of the base of the leaflets, the length of the brachyblasts, the number of flowers per brachyblast and the wings of the fruit (Table 3).

Derris spanogheana, only known from the type collection, is almost identical with D. cebuensis differing only in the slightly higher number of flowers per brachyblast. The type specimen was collected at Timor, which fits within the distribution of D. cebuensis (Philippines, Celebes, Lesser Sunda Islands). The differences are too small to keep the two apart. As D. spanogheana is the oldest name it has priority over D. cebuensis. The two species are united here:

\section{Derris spanogheana Blume ex Miq.}

Derris spanogheana Blume ex Miq. (1855) 141; Benth. (1860) 111. - Type: Spanoghe s.n. (holo $\mathrm{L}$; iso $\mathrm{K}, \mathrm{L}, \mathrm{U})$, Timor.

Derris cebuensis Merr. (1912) 273; (1923) 299. - Type: BS 11014 (Ramos) (holo PNH†; iso K), Philippines, Cebu.

Derris surigaoensis Elmer (1915) 2733. - Type: Elmer 13493 (iso K), Philippines, Mindanao.

Derris rubrocalyx differs only slightly from $D$. spanogheana. Apart from the differences given in Table 3, only the indumentum (D. rubrocalyx somewhat more hairy) and the shape and the size of the flower parts are different. Derris rubrocalyx is a New Guinean endemic. For the present I think it is better to keep the species separate from D. spanogheana.

Also D. trifoliata is rather similar to $D$. spanogheana. The most important differences are found in the number of flowers per brachyblast and the wings of the pod (Table 3 ). Derris trifoliata is a widespread, mostly coastal species, rarely found more inland (up to c. $400 \mathrm{~m}$ ). Derris spanogheana and D. rubrocalyx are inland species (up to c. $650 \mathrm{~m}$ ).

\section{KEY TO THE SPECIES IN MALESIA}

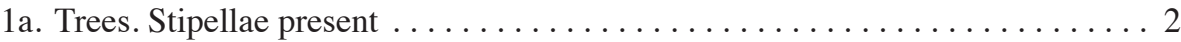

b. Lianas. Stipellae present or absent. . . . . . . . . . . . . . . 4

2a. Leaves with 7-23 leaflets. Stipellae 0.7-3 mm long. Terminal leaflets 18-56 by $9-26 \mathrm{~mm}$, apex obtuse, rounded or acute, mucronate. Brachyblasts with $3-5$

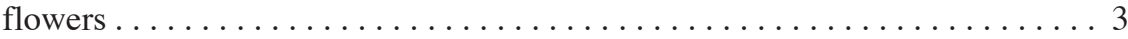

b. Leaves with 19-41 leaflets. Stipellae 0.4-0.7 mm long. Terminal leaflets 14-19 by 5-9 mm, apex rounded, emarginate. Brachyblasts with 5-8 flowers. - Ovules 11 or $12 \ldots \ldots \ldots \ldots \ldots \ldots \ldots \ldots \ldots \ldots \ldots \ldots \ldots \ldots \ldots$. microphylla

3a. Ovules 2 . Seeds 1 or 2 per pod, bean-shaped, $6.5-8$ by $4.5-6$ by $1 \mathrm{~cm}$. - Philip-

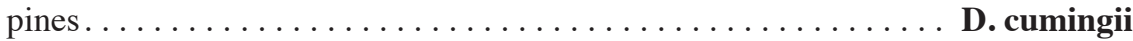

b. Ovules $8-11$. Seeds $1-7$ per pod, ellipsoid, $4-4.5$ by $3-5$ by $0.6-1.5 \mathrm{~cm}$. - India, Burma, Thailand, Java . . . . . . . . . . . . . . . . . . D. robusta

4a. Stipellae present (may be caducous). Pods 1-, rarely 2-winged (not known for

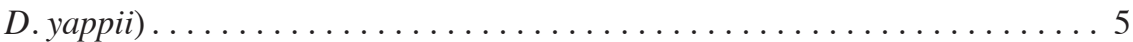

b. Stipellae absent. Pods 1 - or 2 -winged $\ldots \ldots \ldots \ldots \ldots \ldots \ldots \ldots \ldots \ldots \ldots \ldots \ldots \ldots \ldots$ 
5a. Leaves with 3-9 leaflets. Leaflets glabrous or woolly, velvety, hirsute, or with scattered appressed hairs below $\ldots \ldots \ldots \ldots \ldots \ldots \ldots \ldots \ldots \ldots \ldots \ldots \ldots \ldots$

b. Leaves with 9-13 leaflets. Leaflets thinly strigose below. - Ovules $8-10 \ldots \ldots$

D. scandens

6a. Leaflets glabrous below. Calyx outside mostly glabrous, ciliate. Ovules (2 or)

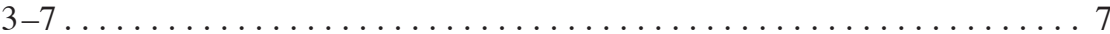

b. Leaflets woolly, velvety, hirsute or with scattered appressed hairs below. Calyx outside (thinly) sericeous. Ovules $2-5$ or $7-10 \ldots \ldots \ldots \ldots \ldots$

7a. Base of leaflets cuneate to rounded. Brachyblasts with up to 15 flowers. Standard with some hairs. Pods 2 -winged $\ldots \ldots \ldots \ldots \ldots \ldots \ldots$ D. rubrocalyx

b. Base of leaflets slightly cordate to (sub)peltate, rarely rounded. Brachyblasts with 2 or 3 (rarely up to 7) flowers. Standard glabrous. Pods 1-winged. D. trifoliata

8a. Leaflets velvety, hirsute or with scattered appressed hairs to almost glabrous below.

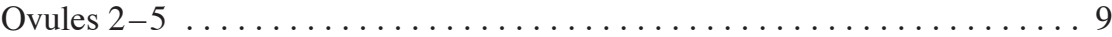

b. Leaflets woolly below. Ovules $7-10$. - Seeds \pm bean-shaped, $8-9$ by $8-10$ by

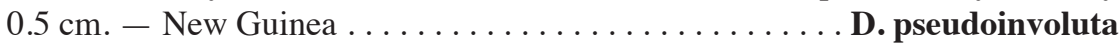

9a. Leaves with 3 or 5 leaflets. Brachyblasts with 2 or 3 flowers. Standard with some hairs to sericeous outside. - Seeds \pm discoid to bean-shaped, $9-14$ by $7-13$ by

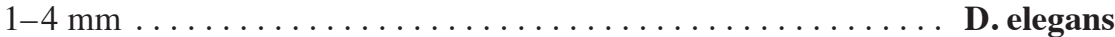

b. Leaves with (3-)7 or 9 leaflets. Brachyblasts with 3-10 flowers. Standard glabrous or with few hairs at the apex $\ldots \ldots \ldots \ldots \ldots \ldots \ldots \ldots \ldots \ldots \ldots \ldots \ldots$ yappii

10a. Leaflets glabrous below. Calyx outside mostly glabrous, ciliate at the margin 11

b. Leaflets with scattered appressed hairs to strigose or hirsute, rarely glabrous below. Calyx outside (thinly) sericeous or hirsute $\ldots \ldots \ldots \ldots \ldots \ldots \ldots \ldots \ldots$

11a. Base of leaflets cuneate to rounded. Brachyblasts with 6-15 flowers. Pods

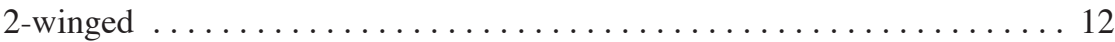

b. Base of leaflets rounded to \pm cordate or subpeltate. Brachyblasts with 2 or 3(-7) flowers. Pods 1 -winged $\ldots \ldots \ldots \ldots \ldots \ldots \ldots \ldots \ldots \ldots \ldots \ldots \ldots \ldots$. trifoliata

12a. Brachyblasts up to $20 \mathrm{~mm}$ long, with 6-8 flowers. Standard outside glabrous or with few hairs at the apex. Pods mostly glabrous, with some hairs at the base, upper wing 5-10 $\mathrm{mm}$, lower wing 4-7 $\mathrm{mm}$ wide . . . . . D. spanogheana

b. Brachyblasts up to $30 \mathrm{~mm}$ long, with up to 15 flowers. Standard outside sericeous at apex or up to halfway down the blade. Pods sericeous at base and apex, upper

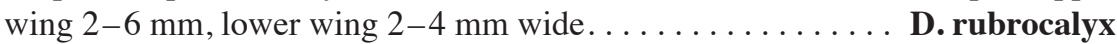

13a. Calyx inside glabrous. Ovules $8-10$. Pods 1 -winged 1 . . . . . . . . . . . 14

b. Calyx inside with few hairs to sericeous along margins, rarely glabrous. Ovules $2-5$. Pods 2 -winged, rarely 1 -winged $\ldots \ldots \ldots \ldots \ldots \ldots \ldots \ldots \ldots \ldots \ldots \ldots \ldots$

14a. Apex of leaflets obtuse to rounded, sometimes acuminate, acumen 2-8 mm long. Brachyblasts $4-11 \mathrm{~mm}$ long. Flowers white to cream or pink. Pods (thinly) seri-

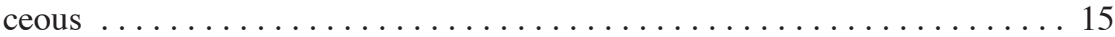

b. Apex of leaflets acuminate, acumen 3-15 mm long. Brachyblasts up to $5 \mathrm{~mm}$ long. Flowers blue or violet. Pods with some scattered hairs to thinly strigose. - Leaves with $5-11$ leaflets, terminal leaflets $5-9.5$ by $3-4.5 \mathrm{~cm}$

1) Flowers not known for D. zambalense. 
15a. Leaves with 5-9 leaflets, terminal leaflets $12-17$ by $7-10.5 \mathrm{~cm}$. Pedicels $1.5-3.5$ $\mathrm{mm}$ long. Standard with 2 small basal callosities. Wing of pod $2-3 \mathrm{~mm}$ wide . . $\ldots \ldots \ldots \ldots \ldots \ldots \ldots \ldots \ldots \ldots \ldots \ldots \ldots$. koolgibberah

b. Leaves with $9-13$ leaflets, terminal leaflets $4-8.5$ by $1-3.7 \mathrm{~cm}$. Pedicels $5.5-9$ $\mathrm{mm}$ long. Standard without callosities. Wing of pod 1-2 mm wide D. scandens

16a. Apex of leaflets acuminate, acumen $2-12 \mathrm{~mm}$ long. Standard outside with some

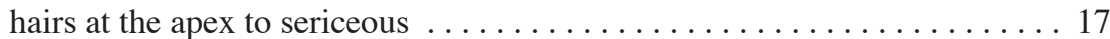

b. Apex of leaflets obtuse to rounded, emarginate, rarely acuminate, acumen 5-6 $\mathrm{mm}$ long. Standard outside glabrous or with some hairs. - Upper wing of pods $2-3 \mathrm{~mm}$, lower wing up to $0.5 \mathrm{~mm}$ wide ............ polyantha

17a. Leaflets not glaucous below. Brachyblasts with 5-7 flowers. Pods with few hairs

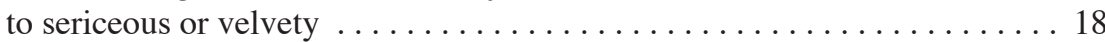

b. Leaflets usually glaucous below. Brachyblasts with 2 or 3 flowers. Pods glabrous. - Pods 2-winged, upper wing 3-4 mm, lower wing $2 \mathrm{~mm}$ wide ....... $\ldots \ldots \ldots \ldots \ldots \ldots \ldots \ldots \ldots \ldots \ldots \ldots \ldots \ldots \ldots \ldots$. maingayana

$18 \mathrm{a}^{2}$. Leaves with 7-11 leaflets. Leaflets sericeous below. Brachyblasts up to $3 \mathrm{~mm}$ long. Calyx outside sericeous. Pods 1-winged, wing 1-2 mm wide ........ $\ldots \ldots \ldots \ldots \ldots \ldots \ldots \ldots \ldots \ldots \ldots \ldots \ldots \ldots \ldots \ldots \ldots \ldots$. philippinensis

b. Leaves with 5-9 leaflets. Leaflets hirsute below. Brachyblasts 2-30 mm long. Calyx outside hirsute. Pods 2-winged, upper wing (3-)6-10 mm, lower wing 2-4 mm wide

D. pubipetala

\section{NOTES ON SPECIMENS}

1. Kep 17075 (E.J.S.), Peninsular Malaysia, Selangor, Batu Caves, 26.12.1932. Climber. Leaflets similar to those of D. rubrocalyx, D. spanogheana and D. trifoliata. Pods have two wide wings .

2. Larsen \& Larsen 32828 , Thailand, Peninsular, Naratiwat, Sungei Kolok, Nihan Waeng, 2.3.1974.

According to the label a tree. The leaves, trifoliolate with stipellae, are quite similar to those of D. elegans.

3. Lae 77222 (J.S. Womersley), Papua New Guinea, N Solomon Prov., Kieta subprov., below Bako on N side of Jaba River, 10.12.1981.

A liana with a large pseudopanicle. The ovary is hairy inside along the lower suture; ovules 3. This specimen differs in several aspects from all New Guinean Derris-species. Pods are needed for a final decision.

4. PNH 9228 (R.B. Fox), Philippines, Polilio Island, Karlagan, 1.3.1949.

This remarkable specimen looks different from all Derris-species in its rather large, thin leaflets and its very long pseudoracemes (33-48 cm long). In several aspects similar to D. scandens, however, the leaflets and flowers are larger and the number of ovules is lower ( $3-5$ instead of $8-10)$.

2) Derris zambalense may key out here. This species is known only in fruit: Pods 2 -winged, upper wing 2-3 mm, lower wing $1 \mathrm{~mm}$ wide. 
5. Derris spec. B, Verdc. (1979) 327. Papua New Guinea: Regalado \& Takeuchi 1487, E Sepik Prov.,Ambunti Subprov., Waskuk Hills, around Langu and Garuka Villages, 5.7.1995; Takeuchi \& Regalado 10280, E Sepik Prov., Ambunti Subprov., Waskuk Hills, ridge near Langu, 5.7.1995; NGF 49977, Morobe Prov., Lae Subprov., Leron River near bridge, 3.5.1977; LAE 77105, Milne Bay Prov., Alotau Subprov., Karoi River above Gurney airport, 12.3.1984; Hartley 10205, Morobe Prov., Markham River valley near Nadzab, 23.5.1962.

These specimens are similar in several aspects to D. koolgibberah and D. rubrocalyx. Particularly in the shape and size of the leaflets and in the hairiness of the anthers. In other characters they are different from or intermediate between $D$. koolgibberah and D. rubrocalyx. Leaflets: in 'Spec. B' ratio length/width (1.4-)1.6-3.5, lower surface glabrous to thinly sericeous; in D. koolgibberah: ratio 1.1-2.1, lower surface thinly to densely sericeous; in D. rubrocalyx: ratio 1.3-2, lower surface glabrous. Standard at most thickened at base without distinct callosities in Derris spec. B and D. rubrocalyx, with small basal callosities in D. koolgibberah. 'Spec. B' has 2-8 ovules, D. koolgibberah 10 and D. rubrocalyx 3-5.

Derris trifoliata, which in some aspects is quite similar to D. koolgibberah and D. rubrocalyx, differs from 'Spec. B' in the base of the leaflets, calyx characters and anthers (glabrous in D. trifoliata).

All specimens of 'Spec. B' are in flower and fruits are needed for a correct placing.

6. Derry 1223, Malaysia.

This specimen with large pods with rather wide wings (pods $9-11$ by $3.5-4$ $\mathrm{cm}$, upper wing c. $8 \mathrm{~mm}$, lower wing c. $4 \mathrm{~mm}$ wide) is in some characters similar to D. amoena. The plant differs from that species in being more hairy, in its smaller flowers and large wide winged pods. In Thailand, Laos, Cambodia and Vietnam several species with similar pods have been described, however, the knowledge of these species is at present insufficient to make a good comparison.

7. PNH 80401 (M.C. Conklin \& Buwaya), Philippines, Luzon, Mt Prov., Bayninan, Banaue, 31.3.1963.

A rather hairy specimen with leaves with 3 or 5 leaflets, apex of leaflets obtuse to rounded, emarginate, ovary with 4 ovules. In some aspects similar to $D$. polyantha which has usually more leaflets (5-9) per leaf.

8. Coode 5877, Celebes, $\mathrm{N}$ coast of Luwuk Peninsula, Pagimana area, inland from Lobu, W of Pagimana, 10.10.1989.

This specimen is in several aspects quite similar to D. polyantha from the Philippines and Lesser Sunda Islands. It differs from that species mostly in the shape of the leaflets: in Coode 5877 narrowly obovate, in $D$. polyantha (narrowly) elliptic.

9. De Vriese \& Teijsmann s.n., Java, 1859-1860; Zollinger 3816 (without locality).

These specimens are similar in several aspects to D. pubipetala and D. scandens. It differs from the first species in the calyx which is rather inconspicuously lobed and glabrous inside, in the indumentum of the wing petals which have hairy auricles, and 
in the hairy anthers. From the second one it differs in the size of the flowers and the hairy anthers. Hairy anthers occur in D. koolgibberah and D. rubrocalyx, both from New Guinea (see also above, 5).

10. Schmutz 2169, 2856, Lesser Sunda Islands, Flores.

In many aspects rather similar to D. pubipetala. These Schmutz-specimens differ from that species in the size of the stipules, bracts and flower parts, in the apex of the leaflets (obtuse to rounded instead of acuminate) and in its indumentum (rather dense on all parts, more or less velutinous instead of hirsute). The shape of the apex of the leaflets is similar to that of $D$. polyantha. Adding these specimens to either $D$. polyantha or D. pubipetala will obscure the differences between these two species.

\section{DUBIOUS SPECIES}

Derris affinis Benth. (1852) 252. - Type: Wall. Cat. 5879, Penang.

Up to now I have not seen the type specimen. It is impossible to place this species.

Derris oligosperma K. Schum. \& Lauterb. (1901) 361; Verdc. (1979) 323. - Type:

Lauterbach 1170 (K, fragments), Papua New Guinea, Gogolfluss.

The fragments at Kew (1 leaflet, parts of a pod) are quite similar to the leaflets and pods of $D$. koolgibberah Verdc. and D. submontana Verdc. A more complete duplicate will show that one of these names has to be replaced by $D$. oligosperma.

Derris pubinervis (Span.) Benth. (1860) 197. - Dalbergia pubinervis Span. (1841)

197. - Type: Spanoghe s.n., Timor, Koepang (n.v.).

Described by Spanoghe with diadelphous stamens. The specimen has not been traced in L. Probably it does not belong to a Derris species.

Millettia rufa Backer (1945) 511; Backer \& Bakh.f. (1964) 596. - Dorgelo 1770 (L), Java, Kediri, baai van Popoh.

The fragments of the type specimen in $\mathrm{L}$ are insufficient for an identification. My earlier suggestion that it may be a Derris species (Adema, 2000) cannot be supported.

Pterocarpus frutescens Blanco (1837) 562. - Galedupa frutescens Blanco (1845) 391; (1879) 354, t. 232.

According to Merrill (1918: 185, 186) this should be either Derris trifoliata (sub Pterocarpus frutescens, p. 185) or D. scandens (sub Galedupa frutescens, p. 186). His Species Blancoana 535, however, belongs to D. cumingii. Blanco's description and plate can be identified either as D. cumingii or as D. scandens. Pterocarpus/Galedupa frutescens is described by Blanco as a tree with stipellae at the base of the petiolules which points to D.cumingii. However, in a note in the third edition of the Flora Filipinas, Blanco wrote: 'Frutescens scandens'. The leaflets are described as emarginate at apex which points to $D$. scandens. This species sometimes has stipellae. The fruit, indumentum and number of leaflets may be correct for both D. cumingii and D. scandens. 


\section{EXCLUDED SPECIES}

Derris amherstiana Thoth. (1976) 59. - Type: J.H. Lace 4723 (holo CAL), Burma, Amherst distr., Thaungyin Valley, Ta' ok Chaung, 18.3.1904. = Spatholobus acuminatus Benth. See Ridder-Numan \& Wiriadinata (1985, in Identification list).

Derris atroviolacea Elmer (1913) 1798. - Type: Elmer 13105 (A, BO, GH, K, L, U), Philippines, Palawan, Puerto Princesa, Mt Pulgar. $=$ Kunstleria forbesii Prain. See Ridder-Numan \& Kornet (1994) 471.

Derris bonatiana Pamp. (1910) 8. - Lectotype (Van der Maesen, 1985): Ducloux 377 (holo FI n.v.), China, Yunnan-sen, source of the Pe-Long-Tan River, 8 May 1904. = Pueraria peduncularis (Graham ex Benth.) Benth. See Van der Maesen (1985).

Derris canarensis (Dalzell) Baker (1879) 246. - Pongamia canarensis Dalzell (1850) 37. - Neotype (Thothathri, 1982): Ritchie 1720 (holo CAL), India, Kanara, Mysore, Kassaleh. $=$ Paraderris canarensis (Dalzell) Adema. See Adema (2003).

Derris canescens Elmer (1919) 3087. - Type: Elmer 17883 (holo ?; iso CAL, L), Philippines, Luzon, Prov. Laguna, Los Baños, Mt Maquiling, 6.7.1917 = Dalbergia canescens (Elmer) Merr. See Merrill (1923).

Derris caudata Backer (1945) 513. - Type: Backer 7061 (BO n.v.), Java, Bantam, Menés, on river bank. = Paraderris montana (Benth.) Adema. See Adema (2003).

Derris cuneifolia Benth. (1852) 253. - Lectotype (Thothathri, 1982): Wall Cat. 5887 (holo CAL; iso K), Nepal, Nookate. $=$ Paraderris cuneifolia $($ Benth.) Geesink. See Geesink (1984), Adema (2003).

Derris cuneifolia Benth. var. longipedicellata Thoth. (1961) 191; (1982) 15. - Type: Ribu 760 (holo CAL), India, Sikkim, Sivoke. = Paraderris cuneifolia (Benth.) Geesink. See Adema (2003).

Derris cuneifolia Benth. forma assamica Thoth. (1961) 192; (1982) 15. - Type: U. Kanjilal 4835 (holo CAL), Assam, Cachar, Bishnupur. = Paraderris cuneifolia (Benth.) Geesink. See Adema (2003).

Derris danauensis Backer (1945) 513 . - Type: Van Steenis 10539 (BO n.v., L), Java, Rawa Danau, on hoema's (fields), alt. c. 120 m. = Paraderris montana (Benth.) Adema. See Adema (2003).

Derris diadelphous (Blanco) Merr. (1910) 103. - Pterocarpus diadelphous Blanco (1837) 563. - Neotype: Merrill Species Blancoana 344, Philippines, Palawan. = Aganope heptaphylla (L.) Polhill.

Derris discolor Benth. (1860) 111. - Type: J.D. Hooker s.n. (holo K; iso K), Sikkim, Terai, lower hills . = Paraderris cuneifolia (Benth.) Geesink. See Adema (2003).

Derris elliptica (Wall.) Benth. (1860). - Pongamia elliptica Wall. (1832) 20, t. 237. - Type: Wall. Cat. 5881A (iso CAL, fragments), Hort. Calcutta (originally from Ambon). = Paraderris elliptica (Wall.) Adema. See Adema (2003). 
Derris elliptica (Wall.) Benth. var. chittagongensis Thoth.(1961) 195. - Type: Baldal Khan 450 (C) (holo CAL; iso CAL), India, Chittagong, Kodla, $30 \mathrm{mi}$ from Chittagong. $=$ Paraderris elliptica (Wall.) Adema var. chittagongensis (Thoth.) Adema. See Adema (2003).

Derris elliptica (Wall.) Benth. var. glaucophylla (Miq.) Kaneh. \& Hatus. (1942) 364. - Pongamia volubilis Zoll. \& Moritzi var. glaucophylla Miq. (1855) 149. Lectotype (Adema, 2003): Anonymous s.n. (holo L, NHN-L 908.114-971), Java. = Paraderris elliptica (Wall.) Adema. See Adema (2003).

Derris floribunda (Miq.) Benth. (1860) 105. - Aganope floribunda Miq. (1855) 151. - Lectotype?: = Aganope thyrsiflora (Benth.) Polhill. See Polhill (1971).

Derris glauca Merr. \& Chun (1935) 246. - Type: F.C. How 70860 (n.v.), China, Hainan. $=$ Paraderris cuneifolia (Benth.) Geesink. See Adema (2003).

Derris hainanensis Hayata (1913) 77. - Type: K. Katsumada s.n. (n.v.), China, Hainan, 1911. = Paraderris hainanensis (Hayata) Adema. See Adema (2003).

Derris hancei Hemsl. (1905) t. 8008 (after D. alborubra Hemsl.). - Type: Sampson s.n. (n.v.), China, Canton, along river. = Paraderris cuneifolia (Benth.) Geesink. See Adema (2003).

Derris heptaphylla (L.) Merr. (1917) 273; Burkill (1935); Backer \& Bakh.f. (1964) 616. - Sophora heptaphylla L. (1753) 373. - Type: Hermann s.n. (BM), Ceylon. = Aganope heptaphylla (L.) Polhill. See Polhill (1971).

Derris indica (Lam.) Bennet (1972) 303. - Galedupa indica Lam. (1788) 594. - Type: Sonnerat s.n. (Herb. Lamarck?), India. = Millettia pinnata (L.) Panigrahi.

Derris indica (Lam.) Bennet var.xerocarpa (Hassk.) Bennet (1972) 303. - Pongamia glabra Vent. var. xerocarpa (Hassk.) Prain (1897) 95. - Type: Anonymous, Java, Bantam, 1841 (n.v.). = Millettia pinnata (L.) Panigrahi.

Derris javanica Miq. (1855) 143. - Type: Horsfield s.n.(Leg.29) (K), Java. = Clitoria ternatea $\mathrm{L}$.

Derris lacei Dunn (1914) 208. - Lectotype (Adema, 2003): Lace 6115 (holo K; iso CAL), Burma, Maymyo, Plateau, 12.3.1913. = Paraderris lacei (Dunn) Adema. See Adema (2003).

Derris laotica Gagnep. (1911) 348. - Type: Magnien, Gourgand \& Châtillon s.n. (lectoholo P (Phan Kê Lôc \& Vidal, 2001); iso K, fragments), Cambodia, Bhâklon. = Paraderris laotica (Gagnep.) Adema. See Adema (2003).

Derris laotica Gagnep. var. virens Gagnep. (1911) 348. — Lectotype (Phan Kê Lôc \& Vidal, 2001): Godefroi 686 (P n.v.), Cambodia, Siem Reap. = Paraderris laotica (Gagnep.) Adema. See Adema (2003). 
Derris leytensis Merr. (1914) 361. - Type: Wenzel 841, Philippines, Leyte, Buenavista, near Jaro, 5.6.1914. = Spatholobus littoralis Hassk. See Ridder-Numan \& Wiriadinata (1985).

Derris lianoides Elmer (1907) 228. - Type: Elmer 7443 (holo PNH?; iso CAL, K), Philippines, Luzon, Prov. Taybas, Luchon. = Paraderris lianoides (Elmer) Adema. See Adema (2003).

Derris lushaiensis Thoth. (1972) 104. - Type: Gage 23D (A) (holo CAL), India. = Paraderris lushaiensis (Thoth.) Adema. See Adema (2003).

Derris macroloba Miq. (1860) 297. - Type: Teijsmann s.n. (H.B. 4216) (holo U?), Sumatra, Lampong. = Aganope heptaphylla (L.) Polhill.

Derris macrophylla (Miq.) Benth. (1860) 114. - Aganope macrophylla Miq. (1855) 152. - Type: Blume s.n . (holo L), Java. = Aganope thyrsiflora (Benth.) Polhill. See Polhill (1971).

Derris malaccensis (Benth.) Prain (1897) 107. - Derris cuneifolia Benth. var. malaccensis Benth. (1860) 112. - Paraderris malaccensis (Benth.) Adema (2001) 11. - Type: Griffith 1774 (holo K; iso CAL), Malaysia, Malacca. = Paraderris montana (Benth.) Adema. See Adema (2003).

Derris malaccensis (Benth.) Prain var. aptera Prain (1897) 108. - Lectotype (Adema, 2003): King's collector 4518 (holo K; iso A, CAL), Malaysia, Perak. = Paraderris montana (Benth.) Adema. See Adema (2003).

Derris malaccensis (Benth.) Prain var. millettioides Prain (1897) 108. - Type: King's collector 10696 (iso CAL), Malaysia, Perak, 8.1886. = Paraderris montana (Benth.) Adema. See Adema (2003).

Derris montana Benth. (1852) 253; (1860) 113. - Type: Junghuhn s.n. (BO? n.v.), Java, Dieng. = Paraderris montana (Benth.) Adema. See Adema (2003).

Derris oblonga Benth. (1860) 112. - Syntypes: Stocks s.n., India, Concan; Gardner 476, Ceylon; Walker s.n., Ceylon; Thwaites 1493, Ceylon. = Paraderris canarensis (Dalzell) Adema. See Adema (2003).

Derris oblongifolia Merr. (1912) 82. - Type: Vanoverberg 280 (n.v.), Philippines, Luzon, Subprov. Bauco, Bontoc. = Paraderris oblongifolia (Merr.) Adema. See Adema (2003).

Derris pachycarpa Merr. (1922) 312. - Type: BS 1250 (M. Ramos) (holo ?; iso K), Borneo, Sabah, Batu Lima, near Sandakan, 9.12.1920. = Paraderris montana (Benth.) Adema. See Adema (2003).

Derris palawanensis Elmer (1913) 1800. - Type: Elmer 13063 (holo ?; iso K, L, U), Philippines, Palawan, Puerto Princesa, Mt Pulgar, 4.1911 . = Spatholobus macropterus Miq. See Ridder-Numan \& Wiriadinata (1985) 178. 
Derris pyrrothyrsa Miq. (1860) 299. - Type: Teijsmann s.n. (holo U; iso L), Sumatra. = Aganope thyrsiflora (Benth.) Polhill. See Adema (2003)

Derris sinuata Benth. ex Thwaites (1859) 93; Benth. (1860) 113; Prain (1897) 98; K. Heyne (1916) 307; Ridl. (1922) 594. - Syntypes: Thwaites 1491 (K), Ceylon, Caltura District; Gardner s.n.(K), Ceylon, Batticalao.= Aganope heptaphylla (L.) Polhill. See Polhill (1971).

Derris subalternifolia Elmer (1913) 1801. - Dalbergia subalternifolia (Elmer) Merr. (1915) 14. - Type: Elmer 12965 (holo ?), Philippines, Palawan, Puerto Princesa, Mt Pulgar, 4.1911. = Dalbergia rostrata Hassk. See Sunarno \& Ohashi (1996).

Derris subavenis Miq. (1860) 299. - Type: Teijsmann s.n. (holo U; iso L), Sumatra. = Aganope thyrsiflora (Benth.) Polhill. See Polhill (1971).

Derris thyrsiflora (Benth.) Benth. (1860) 114; Merr. (1910) 103; Ridl. (1922) 594; Merr. (1923) 301; Craib (1928) 493; Burkill (1935) 791; Backer \& Bakh.f. (1964) 618. - Millettia thyrsiflora Benth. (1852) 249; Miq. (1855) 156. - Lectotype (Phan Kê Lôc \& Vidal, 2001): Griffith 1776 (holo K; iso CAL, LE, P), Malacca. = Aganope thyrsiflora (Benth.) Polhill. See Polhill (1971).

Phan Kê Lôc \& Vidal (2001) cite the locality of Griffith 1776 as 'Birmanie et Péninsule malaise’. However, Griffith 1776 was collected at Malacca, Peninsular Malaysia. The Kew Herbarium is probably the proper place of the (holo)lectotype instead of Paris.

Derris truncata Craib (1927) 385. - Type: Kerr 8898 (holo K), Thailand, Pitsanaloh, Nakawn, Tai. = Paraderris cuneifolia (Benth.) Geesink. See Adema (2003).

\section{ACKNOWLEDGEMENTS}

The loan of material from the herbaria A, AAU, CAL, K, L, LAE, PNH, SING, U, WAG is gratefully acknowledged. The Keeper of the herbarium and the members of the Leguminosae group at Kew are thanked for the hospitality during my visit there. Jan Frits Veldkamp kindly translated the diagnosis of Derris elegans var. celebica into Latin. Ms. Anita Walsmit Sachs skilfully prepared the beautiful illustrations.

\section{REFERENCES}

Adema, F. 2000. Notes on Malesian Fabaceae (Leguminosae-Papilionoideae). 7. The genus Millettia. Blumea 45: 403-425.

Adema, F. 2001 ('2002'). Notes on Malesian Fabaceae XX. Derris in Thailand and Malesia. Thai For. Bull., Bot. 28: 2-16.

Adema, F. 2003. Notes on Malesian Fabaceae (Leguminosae-Papilionoideae). 9. The genus Paraderris. Blumea 48: 129-144.

Backer, C.A. 1945. Notes on the Flora of Java II. Blumea 5: 490-525.

Backer, C.A. \& R.C. Bakhuizen van den Brink Jr. 1964. Flora of Java 1. Noordhoff, Groningen.

Baker, J.G. 1879. Leguminosae. In: J.D. Hooker, Flora of British India 2: 56-306. Reeve \& Co., London.

Bennet, S.S.R. 1972. The taxonomic status of the genus Pongamia Vent. (Papilionaceae). J. Bombay Nat. Hist. Soc. 68: 302, 303. 
Bentham, G. 1852. Leguminosae. In: F.A.W. Miquel, Plantae Junghuhnianae: 205-269. Sythoff, Leiden.

Bentham, G. 1860. Synopsis of Dalbergieae, a tribe of Leguminosae. Proc. Linn. Soc. 4, Suppl.: $1-134$.

Blanco, M. 1837. Flora Filipinas. Manila.

Blanco, M. 1845. Flora Filipinas, ed 2. Manila.

Blanco, M. 1879. Flora Filipinas, ed. 3. Manila.

Buijsen, J.R.M. 1988. Revision of the genus Fordia (Papilionaceae: Millettieae). Blumea 33: 239-261.

Burkill, I.H. 1935. A dictionary of the economic products of the Malay Peninsula. Crown Agents for the Colonies, London.

Craib, W.G. 1927. In: Anonymous, Contributions to the Flora of Siam. Additamentum 23. Kew Bull. 27: 374-395.

Craib, W.G. 1928. Florae Siamensis Enumeratio 1. Siam Society, Bangkok.

Dalzell, N.A. 1850. Contributions to the botany of Western India. Hooker's J. Bot. 2: 33-41.

Dasuki, U.A. \& A.M. Schot. 1991. Taxonomy of Fordia Hemsley (Papilionaceae: Millettieae). Blumea 36: 191-204.

De Lamarck, J.B.A.P.M. 1788. Encyclopédie Méthodique, 2, 2. Panckoucke, Paris.

De Vogel, E.F. 1979. Seedlings of dicotyledons. Pudoc, Wageningen.

Dunn, S.T. 1914. In: Anonymous, Decades Kewenses. Plantarum Novarum in Horti Regii conservatum. Decas 80. Kew Bull. 1914: 205-210.

Elmer, A.D.E. 1907. Some new Leguminosae. Leafl. Philipp. Bot. 1: 220-232.

Elmer, A.D.E. 1913. Four score of new plants. Leafl. Philipp. Bot. 5: 1751-1853.

Elmer, A.D.E. 1915. Two hundred twenty six new species 11. Leafl. Philipp. Bot. 8: 2719-2883.

Elmer, A.D.E. 1919. New woody plants from Mount Maquiling. Leafl. Philipp. Bot. 8: 30693105.

Gagnepain, F. 1911. Classification des Derris d'Extrême-Orient et descriptions d'espèces nouvelles. Not. Syst. 2: 341-350.

Geesink, R. 1984. Scala Millettiearum. Leiden Bot. Ser. 8.

Hayata, B. 1913. Icones Plantarum Formosanarum 3. Govt. of Formosa, Taikohu.

Hemsley, W.B. 1895. Flora of the Solomon Islands. Kew Bull. 1895: 132-139.

Hemsley, W.B. 1905. Derris alborubra. Bot. Mag. 131: t. 8008.

Heyne, K. 1916. De nuttige planten van Nederlandsch-Indië 2. Batavia.

Kanehira, R. \& S. Hatusima. 1942. The Kanehira-Hatusima collection of New Guinean plants XII. Leguminosae. Bot. Mag. Tokyo 56: 356-373.

Linnaeus, C. 1753. Species Plantarum. Holmiae.

Merrill, E.D. 1910. An enumeration of Philippine Leguminosae with keys to the genera and species (concluded). Philipp. J. Sci., Bot. 5: 95-136.

Merrill, E.D. 1912. New or noteworthy Philippine plants IX. Philipp. J. Sci., Bot. 7: 259-357.

Merrill, E.D. 1914. Plantae Wenzelianae II. Philipp. J. Sci., Bot. 9: 353-389.

Merrill, E.D. 1915. New or noteworthy Philippine plants XI. Philipp. J. Sci., Bot. 10: 1-84.

Merrill, E.D. 1917. An interpretation of Rumphius's Herbarium Amboinense. Bureau of Printing, Manila.

Merrill, E.D. 1918. Species Blancoanae. Bureau of Printing, Manila.

Merrill, E.D. 1922. New and noteworthy Bornean plants. J. Straits Branch Roy. Asiat. Soc. 86: $310-342$.

Merrill, E.D. 1923. An enumeration of Philippine flowering plants 2. Bureau of Printing. Manila.

Merrill, E.D. \& W.Y. Chun. 1935. Additions to our knowledge of the Hainan flora II. Sunyatsenia 2: $203-333$.

Miquel, F.A.W. 1855. Flora van Nederlandsch-Indië 1. Van der Post, Amsterdam.

Miquel, F.A.W. 1860. Flora van Nederlandsch-Indië. Eerste bijvoegsel. Sumatra. Van der Post, Amsterdam.

Pampanini, R. 1910. Piante nuove del Yunnan China. Nuov. Giorn. Bot. Ital. N.S. 17: 24.

Perkins, J. 1904. Fragmenta Florae Philippinae. Gebrüder Borntraeger, Leipzig. 
Phan Kê Lôc \& J.E. Vidal. 2001. Flore du Cambodge, du Laos et du Viêtnam. 30. LeguminosaePapilionoideae-Millettieae. Muséum National d'Histoire Naturelle, Paris.

Polhill, R. 1971. Some observations on generic limits in Dalbergieae-Lonchocarpineae Benth. (Leguminosae). Kew Bull. 25: 259-273.

Prain, D. 1897. Order 38. Leguminosae. J. As. Soc. Bengal 66: 21-275.

Pulle, A. 1910. Leguminosae. Nova Guinea 8, 2: 375-387.

Quisumbing, E. 1930. New or interesting Philippine plants I. Philipp. J. Sci. 41: 315-371.

Ridder-Numan, J.W.A. \& D. Kornet. 1994. A revision of the genus Kunstleria (Leguminosae-Papilionoideae). Blumea 38: 465-485.

Ridder-Numan, J.W.A. \& H. Wiriadinata. 1985. A revision of the genus Spatholobus (Leguminosae-Papilionoideae). Reinwardtia 10: 139-205.

Ridley, H.N. 1922. Flora Malay Peninsula 1. Reeve \& Co., London.

Schot, A.M. 1991. Phylogenetic relations and historical biogeography of Fordia and Imbralyx (Papilionaceae: Millettieae). Blumea 36: 205-239.

Schumann, K. \& K. Lauterbach. 1901. Flora der deutschen Schutzgebiete in der Südsee. Gebrüder Borntraeger, Leipzig.

Spanoghe, J.B. 1841. Prodromus Florae Timorensis. Linnaea 15: 161-208.

Sunarno, B. \& H. Ohashi. 1996. Dalbergia (Leguminosae) of Sulawesi, Indonesia. J. Jap. Bot. 71: 241-248.

Thothathri, K. 1961. Studies in Leguminosae 1. A taxonomic revision of the genus Derris Lour. in India. Bull. Bot. Surv. India 3: 175-200.

Thothathri, K. 1970. Studies in the Leguminosae 11. A new species of Derris from the Solomon Islands. J. Arnold Arbor. 51: 251-254.

Thothathri, K. 1972 ('1970'). Studies in Leguminosae 14. Further contributions to the genus Derris Lour. from India. Bull. Bot. Surv. Ind. 12: 104-107.

Thothathri, K. 1976. Derris amherstiana. Bangladesh J. Bot. 4: 59.

Thothathri, K. 1982. Leguminosae: Genus Derris. Fasc. Fl. India 8: 1-33.

Thwaites, G.H.K. 1859. Enumeratio Plantarum Zeylaniae. Dulau \& Co., London.

Van der Maesen, L.J.G. 1985. Revision of the genus Pueraria DC. with some notes on Teyleria Backer (Leguminosae). Agric. Univ. Wageningen Papers 85-1.

Verdcourt, B. 1978. New taxa of Leguminosae from Papua New Guinea. Kew Bull. 32: 455-473. Verdcourt, B. 1979. Manual of New Guinea legumes. Office of Forests, Lae, Papua New Guinea.

Wallich, N. 1832. Plantae Asiaticae Rariores 3. Treuttel \& Würtz, London.

\section{IDENTIFICATION LIST}

$\begin{array}{ll}\text { Derris } & \text { 7. D. polyantha } \\ \text { 1. D. cumingii } & \text { 8. D.pseudoinvoluta } \\ \text { 2. D. elegans } & 9 . \text { D. pubipetala } \\ \text { a. var. elegans } & \text { 10. D. robusta } \\ \text { b. var. celebica } & \text { 11. D. rubrocalyx } \\ \text { c. var. gracillima } & \text { 12. D. scandens } \\ \text { d. var. korthalsiana } & \text { 13. D. spanogheana } \\ \text { 3. D. koolgibberah } & \text { 14. D. submontana } \\ \text { 4. D. maingayana } & \text { 15. D.trifoliata } \\ \text { 5. D. microphylla } & \text { 16. D. yappii } \\ \text { 6. D. philippinensis } & \text { 17. D. spec. }\end{array}$

Achmad 969: 15; 1743: 2d - Aet 458: 2c - Aet \& Idjan 241: 15 - Afriastini 1229: 15; 1520: 12 - Amdja 136: 12; 853: 2d; 876: 2d; 1056: 15 - Anang 646: 15 - Anderson 12244: 2d; 12554: 2d - Anderson \& Keng K68: 15 - Asadt 152a: 15 - Ashton 17782: 2d - Atasrip 98: 15 - Atjeh 49: 15; 108: 15.

Backer 13417: 5; 17300: 9; 17600: 12; 17637: 12; 17790: 12; 24801: 12; 27203: 12; 33868: 12 - Baker 3006: 7 - Bangham 1275: 16 - Bartlett 15160: 15 - Bateson 6: 2c; 35: 15; 97: 15 
- bb 5451: 5; 11136: 12; 14494: 2d; 14495: 17; 14498: 15; 25550: 5 - Beaman, Beaman, Beaman \& Decker 9730: 15 - Beccari PB 30: 15; PB 1088: 15; 2736: 2d - Beguin 464: 15; 1587: 15; 1748: 15 — Bicknell 626: 12; 677: 7; 1190: 7; 1190b: 7; 1393: 12; 1596: 15 — BKF 12364 (Snan): 5; 15437 (B. Sangkhachand): 10; 46390 (P. Suvannakoset): 17 - Bloembergen 3348: 12 - Blume 1151: 12 - BNBFD 1623 (Keith): 2d; 1954 (Mail): 4; 2034 (Taha): 15; 2280 (Cuadra): 15; 2822 (Melegrito): 2d; 2647 (Tandom): 15; 2762 (Puasa): 2d; 3734 (Castro): 2d; 4429 (Castro): 2d; 4959 (Keith): 2d; 9436 (Agama): 15; 10204 (Enggoh): 2d - Boerlage 314: 15 - Bolster 356: 9 - Branderhorst 178: 15 - Brass 1179: 15; 1195: 15; 2723: 2c; 6227: 15; 7251: 2c; 8024: 2c; 8205: 3; 8232: 2c; 8281: 15; 11820: 8; 13913: 2c; 21657: 11; 21824: 11; 21916: 15; 24434: 15; 25494: 3; 25868: 11; 27585: 2c; 27978: 2c; 28164: 15; 29202: 3; 29494: 3; 32288: 8 - Brooke 8818: 15 - Bruggeman 870: 15 - Brun 104 (Ashton): 15 - BS 41 (Ramos): 1; 180 (Ahern's collector): 7; 204 (native collector): 4; 354 (native collector): 15; 412 (Merrill): 12; 831 (Foxworthy): 9; 921 (Mangubat): 15; 1306 (Merrill): 2d; 1396 (Maximo): 12; 1612 (native collector): 15; 1649 (Ramos): 15; 1715 (McGregor): 15; 1855 (Ramos): 12; 1922 (Foxworthy): 1; 2019 (Robinson): 2d; 2188 (Ramos)7; 2892 (Ahern's collector): 9; 5045 (Merrill): 6; 7526 (Ramos \& Edaño): 15; 7731 (Edaño): 2d; 10599 (Merrill): 7; 10862 (Celestino): 12; 11014 (Ramos): 13; 13588 (Meyer \& Foxworthy): 12; 13621 (Ramos): 6; 16321 (Reillo): 15; 16675 (Clemens): 9; 17871 (Otanes): 12; 18281 (Otanes): 9; 27271 (Ramos): 9; 39669 (Ramos): 9; 41507 (Ramos): 13; 44220 (Ramos \& Edaño):15; 47169 (Ramos \& Edaño): 6; 49040 (Ramos \& Edaño): 15; 77332 (Edaño): 2d; 79150 (Edaño): 6; 80635 (Ramos): 15 - Bünnemeyer 6552: 4; 6665B: 15; 7574: 15 - H.M. Burkill 1832: 15; 1902: 4 - I.H. Burkill \& Shah 2498: 15 - Burley 88: 12; 193: 9 - Burn-Murdoch 141: 2a - Buwalda 5260: 2c; 6035: 15; 6964: 2d; 7283: 12 - BW 996 (Schram): 15; 3635 (Kalkman): 15; 4022 (v.d. Syde): 15; 4842 (Versteegh): 15; 5982 (Schram) 2c; 9807 (Moll): 11; 9823 (Moll): 15; 14878 (Schram): 15; 15002 (Schram): $15 ; 15292$ (Vink \& Vink): 2c.

Carr 11204: 15; 12329: 11; 15988: 14; 16056: 3; 16293: 15 - Cel/I-48: 5 - CF 1826 (Rachman): 2a; 3236 (Yeoh): 5; 4008 (Niatkong): 5 - Chin 983: 17; 1836: 12; 2610: 2d - Chin \& Ahmad Kusen 3167: 15 - Chin \& Mustafa 3305: 2a - Clason-Laarman G67: 15 - Clemens 434: 2d; 484: 2d; 2026: 8; 8162: 14; 8287: 14 11067: 12; 16675: 9; 17165: 9; 21306: 2d; 21797: 2d; 40933: 14 - Coert 700: 15 - Comins 300: 2c - Conn et al. 53: 8 - Coode 5877: 17 - Corner 31611: 5 - Craven \& Schodde 395: 2c; 815: 15 - Cuming 1162: 6; 1208: 1; 1420: 12; 1699: 12; 1844: 15 - Curtis 279: 12; 918: 15; 3439: 15; 3560: 15; 3673: 12 .

Darbyshire 747: 11; 1121: 3 - Davis et al. 567: 11; 578: 2c - De Voogd 2315: 12 - DeVore \& Hoover 250: 12 - J.J.F.E. de Wilde 1213: 15 - W.J.J.O. de Wilde \& De Wilde-Duyfjes 20359A: 2a - Demoulin \& Smeets 5677: 15; 5729: 145 - Derry 291: 4; 545: 4 — Dissing \& Sandermann Olsen 1951: 15 — Docters van Leeuwen 1790: 15; 1892: 12; 9715: 2c; 9926: 14; 10766: 2c; 11266: 2c - Dorgelo 900: 15.

Ebalo 1023: 2d - Elbert 2413: 12; 2414: 15; 2550: 13; 2660: 13; 2698: 13; 2718: 13; 2766: 2b; 2767: 17; 2977: 17; 3057: 2b; 3335: 2b; 3513: 12; 3772: 13; 4461: 12; 4679: 12 - Elmer 6177: 6; 6345: 1; 6463: 12; 7162: 2d; 7797: 9; 8678: 12; 8888: 6; 11738: 9; 11989: 15; 12814: 9 13078: 9; 13463: 13; 13493: 13; 14373: 6; 16785: 15; 16961: 13; 18310: 6; 20610: 15 — Endert 1797: 12; 2048: 2d; $3427: 9$ - Eyma 4079: 15; 4094: 2b; 4128: 2 b.

FB 1129 (Ahern's collector): 1; 1140 (Ahern's collector): 1; 2653 (Ahern's collector): 7; 2892 (Ahern's collector): 9; 2986 (Ahern's collector): 1; 3978 (Hutchinson): 15; 5133 (Curran): 1; 7034 (Curran): 1; 12278 (Curran): 15; 12288 (Curran): 15; 12754 (Shugnell): 5; 26463 (Catalan): 9; 27072 (Guzman): 15; 28951 (Willie \& Salvosa): 6; 29010 (Schneider): 6; 29993 (Cenabre): 12 - FD 9662 (Evakaw): 15 - FM 2564 (J.C. 1634): 15 - FMP 22975 (Symington): 4 - FMS 48 (Barnard): 15; 1882 (CF): 5; 3236 (Ycop?): 5; 12705 (For. Guard): 12; 12758 (Webber): 15 — Forman 588: 15 - FRI 3471 (Whitmore): 16; 16248 (Kochummen): 15; 26557 (Kochummen): 15; 39802 (Saw): 5 — Friedberg 398: 15 - Frodin \& Morren 3361: 15.

Geesink et al. 9346: 9 - Geesink \& Santisuk 5249: 15 - Gibbs 6229: 15 - Gjellerup 598: 2a — Goetghebeur 3352: 15; 3500: 15; 3509: 15 - Goodenough 1829: 5; 1996: 4 - Griffith 1778: $15 ; 1779: 15$.

Hallier 724: 15; 1181: 15; 4251: 15; 7924: 2d - Hamel \& Rahmat si Boeea (= Rahmat si Toroes) 1303: 15 - Haniff 365: 4 - Hartley 10158: 3; 10205: 17; 10436: 15; 10865: 15; 11603: 15 
- Haviland 164: 15; 2898: 15; 2899: 15 - Hays 505: 14 - Hellwig 103: 15 - Henderson 138: 5 - Hennipman 5810: 15 - Herbarium Boschproefstation 2931: 15; 4397: 15; 4768: 12 - Hochreutiner 2079: 15 - Hollrung 429: 2a - Holstvoogd 94: 15 - Hoogerwerf 213: 15 - Hoogland 4291: 15; 5189: 11; 9003: 11 - Hoogland \& Craven 10315: 2c - Horsfield L15: 12; L16: 10; L18: 12; L20: 15 - Hose 361: 2d; 611: 15 - Hosseus 523: 5 - Hullett 563: 4. Iboet 212: 15; 520: 15 - Idjan \& Mochtar 378: 15 - Iserentant 9004: 15.

Jacobs 4916: 12; 9197: 2c - Janowsky 31: 15; 565: 15 - Jeswiet 154 (1171): 15 - Junghuhn 46: 15; 47: 15; 99/100: 15 .

Kadim \& Mahmood 9: 17 - Kairo \& Vinas 809: 2c - Kajewski 1567: 15; 2259: 2c; 2290: 2c - Karta 64: 15 - Kartawinata 1068: 15 - Kasim \& Zainudin 1749: 2a - Kau Ann Soon 18: 17 - Kaudern 531: 12 - Keith 4959: 9 - Keng \& Anderson 68: 2d - KEP 17075 (Sinclair): 17; 27013 (Osman \& Tachon): 15; 27014: 4; 34605 (Saw): 2a; 71947 (Wyatt-Smith): 5; 115659 (Whitmore): 5 - Kerr 13885: 5 - Keßler et al. 1683: 2d - King 5593: 5 - King's coll. 1419: 2a; 2775: 2a; 3039: 5; 3911: 2d; 4014: 2a; 4398: 2a; 5583 (5383?): 2a; 5805: 5; 7398: 2a - KL 1398 (Gadoh anak Umbai): 2a; 2564 (J.C. 1634): 15; 2959 (Teo \& P): 2a - Koch 48 (631): 15 - Køie \& Sandermann Olsen 1276: 15 - Koorders 4300: 10; 4301: 10; 4302: 10; 4303: 10; 4304: 10; 4306: 10; 4311: 10; 4312: 10; 4314: 10; 14216: 10; 17591: 15; 25510: 10; 25518: 10; 26148: 12; 41517: 10 - Kooy 316: 12; 1324: 13 - Kornassi 57: 2c; 189: 15; 213: 15; $764:$ 15; 948: 15 - Korthals 722: 2d - Kostermans 2837: 2c; 2878: 2c; 6117: 2c; 9144: 15; 9920: 2d; 18047: 12; 19202: 12 - Kostermans \& Wirawan 159: 12; 947: 13 - Kunstler 1381: 4.

LAE 6575 (A. Floyd): 15; 52603 (Streimann \& Lelean): 15; 52638 (Streimann \& Lelean): 15; 53719 (Stone \& Streimann): 15; 55338 (Womersley): 15; 56523 (Kerenga): 2a; 61319 (Croft \& Vinas): 15; 66033 (Conn \& Katik): 15; 70306 (Wiakabu \& Yefle): 15; 70527 (Larivita \& Katik): 15; 73335 (Wiakabu): 15; 73396 (Wiakabu, Katik \& Ron): 3; 77105 (Gideon): 17; 77222 (Womersley): 17 - Lam 852: 2c; 2510: 15; 3164: 17 - K. Larsen \& S.S. Larsen 32828: 2a - Laup 58: 2c - Lauterbach 821 (2821): 2a; 1052: 2a - Loeters 1175: 12; 1652: 15; 1902: 12; 1983: 15; 2017: 12 - Loher 1068: 1; 2185: 7; 2186: 9; 2237: 6; 2238: 7; 2246: 6; 2251: 12; 2252: 9; 2256: 15; 2257: 15; 2258: 15; 2259: 15; 2260: 15; 2261: 7; 2262: 1 ; 2263: 1 ; 2264: 1 ; 2265: 1 ; 2269: 12; 2411: 1; 2939: 15; 5927: 6; 5928: 6; 5940: 9; 5945: 6; 5960: 6 - Lörzing 9128: 12; 13397 : 12; 16522: 5 - Lugas 1935: 2d, 2113: 2 d.

Mahmud 827: 5 - Mahyar, Thomas, Sands \& Davis 392: 15 - Main 1806: 15; 1836: 2d; 2147: 2d - Maingay 55 (1165): 4; 603 (1918): 5; 608: 2a; 1551/553: 15; 1553B: 4 - Maxwell 75-972: 17; 79-16: 15; 80-15: 15; 80-165: 15; 80-169: 15; 83-11: 4 - McDonald \& Ismail 4181: 15 - McGregor 339: 12 - McKee 1679: 15 - Meijer 6701: 15 - Meijer Drees 587: 2c - Merrill 666: 2d; 953: 9; 1306: 2d; 1366: 7; 1457: 7; 1692: 7; 1867: 1; 1969: 6; 2284: 9; 2824: 1; 4185: 12; 9483: 2d; 10481: 13 - Merrill species Blancoana 541: 15; 555: 1 - Mills 1: 2a - Mirmanto \& Ruskandi 110: 15 - Mochtar 57: 12 - Moi 131: 15 - Mondi 126: 15 - Monod de Froideville 63 (67): 5; 95: 12 - Motley 860: 2d; 997: 2d - Muditha \& Maskuri 240: 15 - Mulder 80: 4 - Mulyati Rahayu 699: 2d - Murata, Iwatsuki, Kato \& Mogea 2693: 15.

Nachman 397: 15 - Native collector 225: 15 - NBFD A2280 (Cuadra): 15; 10204: 2d - Nedi 104: 15 - NGF 2950 (Womersley): 15; 4196 (Womersley): 3; 5050 (Womersley \& Simmonds): 15; 6522 (Floyd): 2c; 6538 (Floyd): 15; 6575 (Floyd): 15; 6588 (Floyd): 15; 7128 (Womersley \& Simmonds): 2a; 7868 (Henty): 15; 8027 (Gray \& Floyd): 15; 9961 (Millar): 3; 9978 (Millar): 3; 14714 (Henty): 8; 15395 (Womersley): 8; 16506 (Henty): 15; 18069 (Sayers): 15; 19585 (Sayers): 15; 22652 (Millar): 3; 22878 (Millar \& Floyd): 15; 23305 (Millar): 8; 24120 (Sayers): 15; 25238 (Gillison): 15; 25652 (Gillison et al.): 15; 26446 (Frodin): 15; 26475 (Frodin): 14; 27136 (Henty) 15; 27776 (Streimann \& Kairo): 8; 29499 (Henty \& Lelean): 15; 29621 (Coode, Cropley \& Katik): 15; 29803 (Coode, Cropley \& Katik): 15; 30696 (Kairo \& Streimann): 14; 31489 (Isles \& Vinas): 2c; 34504 (Croft \& Katik): 15; 34510 (Croft \& Katik): 15; 35700 (Kairo \& Streimann): 14; 36777 (Ridsdale \& Katik): 2a; 37995 (P. Katik): 15; 40556 (Millar): 14; 40947 (Millar \& Vandenberg): 15; 42174 (Vandenberg): 15; 42347 (Vandenberg \& Katik): 15; 42982 (Henty \& Barlow): 2c; 43013 (Mann \& Osbora): 15; 43331 (Mann): 15; 44193 (Streimann): 15; 46616 (Katik): 2a; 49335 (Henty \& Foreman): 2c; 49977 (Henty et al.): 17 - Noerkas 394: 13; 500: 5 - Nooteboom 1229: 2d; 1290: 9; 5801: 15; 6093: 15. 
Paie 16373: 2d - Paijmans 1614: 15; 1626: 15 - PNH 2625 (Sulit): 13; 5847 (Castro et al.): 12; 6936 (Sulit): 12; 9228 (Fox): 17; 9800 (Ruiz): 12; 11064 (Edaño): 17; 11470 (Edaño): 13; 11505 (Edaño): 13; 12504 (Sulit): 2d; 13768 (Sulit): 13; 14102 (Edaño): 15; 14141 (Edaño): 2d; 14656 (Edaño): 12; 15787 (Conese): 15; 17165 (Sulit): 15; 17166 (Sulit): 15; 17765 (Sulit): 15; 18701 (Conklin): 13; 18726 (Conklin): 12; 18848 (Sulit): 15; 18849 (Sulit): 15; 18867 (Sulit): 15; 20341 (Mendoza): 1; 32809 (Sulit): 13; 32817 (Sulit): 9; 34686 (Pancho): 7; 36254 (Frake): 15; 37861 (Conklin): 15; 38015 (Frake): 13; 38063 (Frake): 13; 38316 (Frake): 13; 78670 (Conklin \& Bawaya): 1; 79797 (Quisumbing \& Del Rosario): 2d; 80401 (Conklin \& Buwaya): 17; 80565 (Conklin \& Buwaya): 12; 81883 (Mendoza): 15; 91257 (Mendoza \& Espirutu): 15; 92130 (?): 7; 97790 (Mendoza): 15; 97797 (Mendoza): 17; 97901 (Mendoza): 15; 97918 (Mendoza): 9 — Podzorski 723: 17 - PPI 2056 (Barbon, Alvarez \& Garcia): 15; 5773 (Barbon, Garcia \& Sagcal): 2d; 8968 (Barbon et al.): 15 — Prawiroatmodjo \& Soewoko 1851: 2b - Pulle 91: 2c — Pullen 1136: 2c; 1412: 15; 3506: 15 - Pursglove \& Shah 4628: 15 - Put 1410: 5.

Raap 428: 15 - Rachmat 369: 2b - Rahmat si Boeea (= Rahmat si Toroes) 2397: 2a; 3224: 2a; 4072: 4; 4086: 4; 4336: 4 - Ramlanto 383: 2d - Rant 1070: 15 - Regalado \& Takeuchi 1487: 17 - Reinwardt '1773': 12; ‘1290': 12 - Res 420: 15 - Ridley 2098: 15; 2639: 12; 3024 : 5; 5234: 15; 6402: 4; 9492: 12; 12626: 5; 15115: 5 - Ridsdale, Dejan \& Baquiran ISU 54: 9 - Riedel 5825: 12 - RLS Herb. Tropicum D26: 10 - Robinson 2019: 2d; Pl. Rumph. Ambon. 537: 15 - Rumuton 349: 2a; 480: 2a - Rutten 60: 15; 62: 15; 430: 15.

S 16373 (Paie): 2d; 17782 (Ashton): 2d; 30052 (Paul Chai): 15; 30762 (Anderson): 15; 31870 (Paul Chai): 15; 34141 (Paul Chai): 2d; 34691 (Paul Chai): 2d; 35131 (Mamit): 15; 40117 (Yii \& Puan Ching): 2d; 45416 (Lee): 2d; 52365 (Lee): 2d; 62439 (Kandau Juang): 15 - Samad 418: 15 - SAN 17291 (Nicholson): 2d; 19567 (Meijer): 17; 21753 (San): 2d; 21802 (Meijer): 4; 26076 (Muin Chai): 9; 32884 (Ampuria): 2d; 33325 (Ampuria): 2d; 33344 (Ampuria): 2d; 34009 (Gibot): 2d; 34191 (Ampuria): 2d; 34204 (Ampuria): 2d; 36960 (Gibot): 2d; 40110 (Sinaggul): 15; 42024 (Gibot): 15; 49168 (Gibot): 15; 68057 (Lantoh): 15; 70381 (Lee \& Madani): 15; 73298 (Lantoh): 2d; 81932 (Kodoh \& Aban): 2d; 83906 (Dewol): 9; 89940 (Aban \& Dewol): 2d; 90782 (Madani): 15; 101463 (Fedilis \& Sumbing): 2d; 106028 (Amin Sigun): 15; 115127 (Amin Sigun): 15; 116078 (Amin Sigun \& Francis): 2a; 116272 (Amin Sigun \& Jarius): 9; 120550 (George et al.): 15; 121970 (Krispinus): 2d; 122101 (Sumbing Jimpin): 2a; 123109 (Amin Sigun et al.): 2a; 123582 (Amin Sigun et al.): 17; 125977 (Ag. Amu): 15; 130228 (Meijer \& Good): 15 - Sands, Pattison \& Wood 2800: 15; 3027: 15 - Sauveur 925: 15 - Schlechter 16697: 2a; 17927: 11 - Schmutz 95: 12; 1690: 13; 1836: 12; 2213: 15; 3804: 9; 4094: 7; 4196: 15; 5360: 12 — Schodde 2667: 2a; 2759: 10 - Schodde \& Craven 4253: 15 - Scortechini 2180: 15 - SF 470 (Burkill): 15; 789 (Spare): 15; 1070 (Haniff): 12; 3775 (Haniff): 12; 7477 (Haniff \& Nur): 12; 12919 (?): 15; 14533 (Boden Kloss): 15; 15115 (?): 5; 15741 (Ridley): 4; 15782 (Burkill \& Haniff): 5; 15902 (Haniff): 15; 16055 (Burkill \& Haniff): 15; 17339 (Burkill \& Haniff): 15; 19233 (Boden Kloss): 12; 19755 (Henderson): 15; 29817 (Corner): 12; 29850 (Corner): 15; 29854 (Corner): 12; 31524 (Corner): 5; 31676 (Corner): 5; 33683 (Milsum): 15; 34493 (Spare): 2a; 36208 (Spare): 2a; 36841 (Ngadiman): 4; 37585 (Kingdon Ward): 9; 38990 (Addison): 4; 40815 (Sinclair \& Kiah bin Salleh): 12 - Shah \& Chang Kian 829: 15 - Shah \& Kadim 955: 15 - Sidek bin Kiah 80: 12 - SMHI 471(Ridsdale): 2d; 2060 (Podzorski): 2d - Soejarto, Fernando \& Majducon 8063: 12; 9065: 9 - Soejarto \& Madulid 6096: 9 - Sterly 80-286: 14 - Stone 6244: 15; 6252: 15; 15558: 15 - Stone, Chin et al. 15235: 4 - Stone \& Mahmud Sidek 12513: 16.

Tadena 4: 12 - Takeuchi 8854: 8 - Takeuchi, Gideon \& Wiakabu 4349: 14 - Takeuchi \& Kulang 11359: 2c - Takeuchi \& Regalado 10280: 17 - Takeuchi \& Wiakabu 10093: 2c - Teijsmann HB 10704: 12; 10713: 12; 11130: 12; 11801: 2b; 12580: 2b; 12593: 2b; HB 13838: 2b - Teruya 1058: 15 - Thomson 851: $2 \mathrm{c}$.

University of San Carlos 849: 15 - UPNG 4135 (Frodin): 15; 6156 (Naoni \& Kuduk): 2c; 6778 (Frodin \& class): 11 .

Van Balgooy 6722: 9; 6913: 15 - Van Balgooy \& Stone 2257: 2a - Van Balgooy et al. 5891: 13 - Van Beusekom \& Phenghklai 665: 9 - Van Borssum Waalkes 249: 2d; 714: 15 - Van Harreveld 3838: 15 - Van Hasselt 76: 12 - Van Niel 3535: 2d; 3945: 15; 3975: 15; 4064: 15; 4065: 12; 4078: 15; 4386: 4 - Van Royen 3301: 15; 3360: 15; 4936: 15 - Van Steenis 3382: 9; 
17480: 12; 18009: 12 - Van Welzen 785: 15 - Varadarajan et al. 1564: 13 - Verdcourt, Henty \& Lelean 5095: 11 - Verdcourt \& Huxley 4877: 11 - Verheijen 720: 13; 1063/64: 12; 1095: 12; 2270: 12; 3282: 12; 3385: 15; 3841: 12; 4510: 15; 4538: 12 - Versteeg 1714: 2c; 1754: 2c — Versteegh 108: 15 - Vidal 187: 12; 260: 7; 262: 1; 739: 12; 1068: 1; 1082: 15; 1084: 6; 1088: 9; 1088bis: 9; 1093: 7; 1257: 12; 1301: 7; 1304: 7; 2564: 7; 2576: 9; 2577: 6; 2578: 7; 2579: 12; 2581: 13; 2582: 15; 2583: 9; 2585: 6; 2586: 12; 2587: 15; 2591: 1; 2593: 2d; 2594: 6; 2595: 1; 2599: 2d; 2600: 15; 2601: 1; 2602: 15; 2658: 9.

Walsh 202: 12 - Waterhouse 826-B: 2c - Wenzel 1271: 12; 1377: 15; 1427: 15; 1530: 13 -

Weston 13522: 15 - Widjaja, Wally \& Subari 6024: 15; 6336: 15 - Williams 714: 6; 1053: 12;

2398: 13; 2746: 15; 2857: 12; 3064: 15 - Winkler 1414: 2d; 3072: 15 - Wirawan 25: 2d; 28: 2d

- Wiriadinata 3339: 15 - Wiriadinata \& Prawiroatmodjo 128: 4 - Wray 2492: 15; 2708: 15. Yapp 203: 16 - Yates 1358: 2a.

Zollinger 3799: 12; 3816: 17.

\section{INDEX}

The accepted names are in roman type, the synonyms and dubious species in italics and the new names and combinations in bold.

Aganope

floribunda Miq. $=$ Aganope thyrsiflora

heptaphylla (L.) Polhill [p. 408, 409, 410, 411]

macrophylla Miq. = Aganope thyrsiflora

thyrsiflora (Benth.) Polhill [p. 409, 410, 411]

Clitoria ternatea L. [p. 409]

Dalbergia

canescens (Elmer) Merr. [p. 408]

pubinervis Span. [p. 407]

rostrata Hassk. [p. 411]

subalternifolia (Elmer) Merr. $=$ Dalbergia rostrata

Derris Lour.

acuminata Miq. $=$ Derris pubipetala

affinis Benth. [p. 407]

amherstiana Thoth. $=$ Spatholobus acuminatus

atroviolacea Elmer $=$ Kunstleria forbesii

bonatiana Pamp. = Pueraria peduncularis

canarensis (Dalzell) Baker $=$ Paraderris canarensis

canescens Elmer $=$ Dalbergia canescens

caudata Backer $=$ Paraderris montana

cauliflora Pulle $=$ Derris elegans var. gracillima

cebuensis Merr. $=$ Derris spanogheana

cuneifolia Benth. $=$ Paraderris cuneifolia

var. longipedicellata Thoth. $=$ Paraderris cuneifolia

var. malaccensis (Benth.) Adema = Paraderris montana

forma assamica Thoth. = Paraderris cuneifolia

danauensis Backer $=$ Paraderris montana

diadelphous (Blanco) Merr. = Aganope heptaphylla

discolor Benth. = Paraderris cuneifolia

elegans Graham ex Benth. [p. 396]

var. celebica Adema [p. 399]

var. elegans [p. 397]

var. gracillima (Hemsl.) Verdc. [p. 399]

var. korthalsiana (Blume ex Miq.) Adema [p. 400]

var. vestita $($ Baker $)$ Prain $=$ Derris elegans var. elegans 
(Derris)

elliptica (Wall.) Benth. $=$ Paraderris elliptica

var. chittagongensis Thoth. $=$ Paraderris elliptica var. chittagongensis

var. glaucophylla (Miq.) Kaneh. \& Hatus. = Paraderris elliptica

ferruginoides Quisumb. $=$ Derris pubipetala

floribunda (Miq.) Benth. = Aganope thyrsiflora

glauca Merr. \& Chun = Paraderris cuneifolia

hainanensis Hayata $=$ Paraderris hainanensis

hancei Hemsl. $=$ Paraderris cuneifolia

heptaphylla (L.) Merr. = Aganope heptaphylla

indica $($ Lam.) Bennet $=$ Millettia pinnata

var. xerocarpa $($ Hassk.) Bennet $=$ Millettia pinnata

javanica Miq. = Clitoria ternatea

koolgibberah F.M. Bailey [p. 401]

subsp. pseudoinvoluta Verdc. $=$ Derris pseudoinvoluta

korthalsiana Blume ex Miq. = Derris elegans var. korthalsiana

lace $i$ Dunn $=$ Paraderris lacei

laotica Gagnep. = Paraderris laotica

var. virens Gagnep. $=$ Paraderris laotica

leytensis Merr. $=$ Spatholobus littoralis

lianoides Elmer $=$ Paraderris lianoides

lushaiensis Thoth. $=$ Paraderris lushaiensis

macroloba Miq. = Aganope heptaphylla

macrophylla $($ Miq.) Benth. = Aganope thyrsiflora

malaccensis (Benth.) Prain $=$ Paraderris montana

var. aptera Prain $=$ Paraderris montana

var. millettioides Prain $=$ Paraderris montana

micans Perkins $=$ Derris pubipetala

mindorensis Perkins $=$ Derris pubipetala

moniensis Kaneh. \& Hatus. = Derris elegans var. gracillima

montana Benth. $=$ Paraderris montana

oblonga Benth. $=$ Paraderris canarensis

oblongifolia Merr. $=$ Paraderris oblongifolia

oligosperma K. Schum. \& Lauterb. [p. 407]

pachycarpa Merr. $=$ Paraderris montana

palawanensis Elmer $=$ Spatholobus macropterus

papuana Pulle $=$ Derris elegans var. gracillima

polyantha Perkins [p. 402]

pseudoinvoluta (Verdc.) Adema [p. 402]

pubinervis (Span.) Benth. [p. 407]

pubipetala Miq. [p. 401]

pyrrothyrsa Miq. = Aganope thyrsiflora

rubrocalyx Verdc. [p. 402, 403]

rufula $\mathrm{K}$. Schum. \& Lauterb. = Derris elegans var. elegans

salomoniensis Thoth. $=$ Derris elegans var. gracillima

sinuata Benth. ex Thwaites = Aganope heptaphylla

spanogheana Blume ex Miq. [p. 403]

subalternifolia Elmer $=$ Dalbergia rostrata

subavenis Miq. = Aganope thyrsiflora

surigaoensis Elmer $=$ Derris spanogheana

thyrsiflora $($ Benth.) Benth. = Aganope thyrsiflora

trifoliata Lour. [p. 396, 402]

truncata Craib $=$ Paraderris cuneifolia

vestita Baker $=$ Derris elegans var. elegans 


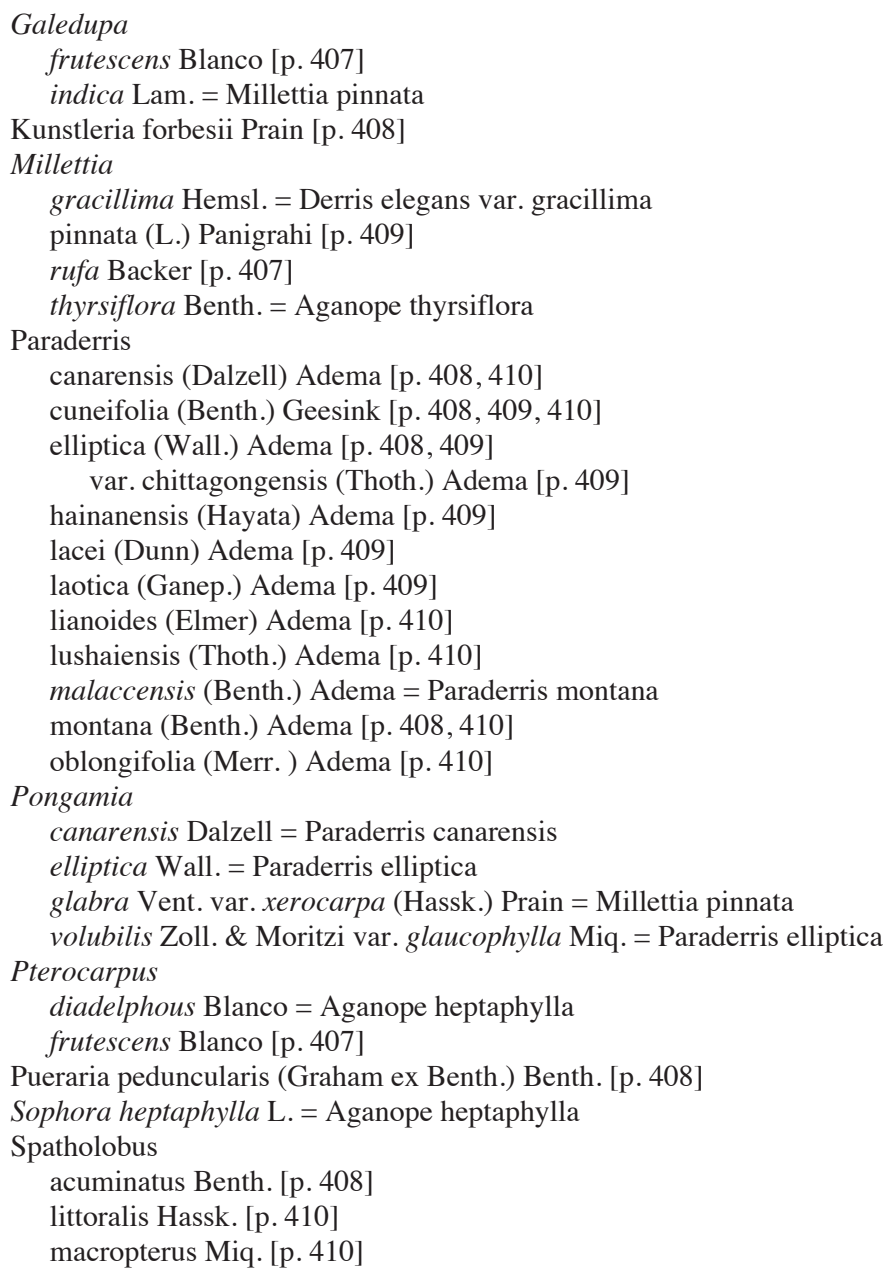

